\title{
Non-destructive handheld XRF study of archaeological composite silver objects - the case study of the late Roman Seuso Treasure
}

\author{
Viktória Mozgai ${ }^{1}$ (D) $\cdot$ Bernadett Bajnóczi ${ }^{1}$ (D) Zoltán May $^{2}$ (I) $\cdot$ Zsolt Mráv $^{3}$
}

Received: 22 November 2020 / Accepted: 15 March 2021 / Published online: 17 April 2021

(C) The Author(s) 2021

\begin{abstract}
This study details the non-destructive chemical analysis of composite silver objects (ewers, situlas, amphora and casket) from one of the most significant late Roman finds, the Seuso Treasure. The Seuso Treasure consists of fourteen large silver vessels that were made in the fourth-early fifth centuries $\mathrm{AD}$ and used for dining during festive banquets and for washing and beautification. The measurements were systematically performed along a pre-designed grid at several points using handheld X-ray fluorescence analysis. The results demonstrate that all the objects were made from high-quality silver (above $90 \mathrm{wt} \% \mathrm{Ag}$ ), with the exception of the base of the Geometric Ewer B. Copper was added intentionally to improve the mechanical properties of soft silver. The gold and lead content of the objects shows constant values (less than $1 \mathrm{wt} \% \mathrm{Au}$ and $\mathrm{Pb}$ ). The chemical composition as well as the $\mathrm{Bi} / \mathrm{Pb}$ ratio suggests that the parts of the composite objects were manufactured from different silver ingots. The ewers were constructed in two ways: (i) the base and the body were made separately, or (ii) the ewer was raised from a single silver sheet. The composite objects were assembled using three methods: (i) mechanical attachment; (ii) low-temperature, lead-tin soft solders; or (iii) high-temperature, copper-silver hard solders. Additionally, two types of gilding were revealed by the XRF analysis, one with remnants of mercury, i.e. fire-gilding, and another type without remnants of mercury, presumably diffusion bonding.
\end{abstract}

Keywords Late Roman · Composite silver objects · Handheld XRF · Seuso Treasure · Chemical composition · Gilding

\section{Introduction}

The Seuso Treasure is one of the most significant treasure finds from the late Roman Imperial period (Painter 1990; Mango and Bennett 1994; Mráv and Dági 2014; Dági and Mráv 2019). The Treasure is composed of 14 large, domestic silver vessels (Fig. 1), as well as the copper cauldron in which they were hidden. The name originates from the owner, Seuso,

Viktória Mozgai

mozgai.viktoria@csfk.org

Bernadett Bajnóczi

bajnoczi.bernadett@csfk.org

1 Institute for Geological and Geochemical Research, Research Centre for Astronomy and Earth Sciences, Eötvös Loránd Research Network (ELKH), H-1112 Budaörsi út 45, Budapest, Hungary

2 Institute of Materials and Environmental Chemistry, Research Centre for Natural Sciences, Eötvös Loránd Research Network (ELKH), H-1117 Magyar tudósok körútja 2, Budapest, Hungary

3 Hungarian National Museum, H-1088 Múzeum körút 14-16, Budapest, Hungary which is written in the metric inscription of one of the platters. The pieces are typical of the period, representing parts of a dining set used during festive banquets and also including vessels for washing, bathing and beauty treatments. The objects of the Seuso Treasure are amongst the largest known late Roman silver vessels, and they are outstanding in both their artistic and material value. Most of the silver vessels were manufactured in the fourth century $\mathrm{AD}$, although some may have also been produced in the early fifth century AD. They were likely hidden in NE Pannonia (present-day Hungary) when the Romans fled from a "barbarian" attack in the late fourth or early fifth century AD (Mráv and Dági 2014; Dági and Mráv 2019).

During the final centuries of the Roman Empire, other silver hoards were similarly hidden underground in various parts of the Empire (e.g. Hoxne (England); Mildenhall (England); Kaiseraugst (Switzerland); Vinkovci (Croatia); Esquiline, Rome (Italy); Traprain Law (Scotland)). X-ray fluorescence (XRF) analysis has been used to examine most of the other Roman silver treasures (Hughes and Hall 1979; Lang et al. 1984; Feugère 1988; Hughes et al. 1989; Lang 2002; Cowell and Hook 2010; Hook and Callewaert 2013; Minning and 
Fig. 1 The Seuso Treasure: 1. Geometric Platter; 2. Meleager Platter; 3. Achilles Platter; 4. Seuso (or Hunting) Platter; 5. Hippolytus Ewer; 6. Hippolytus Situla A; 7. Hippolytus Situla B; 8. Animal Ewer; 9. Dionysiac Ewer; 10. Amphora; 11. Toilet Casket; 12. Geometric Ewer A; 13. Basin; 14. Geometric Ewer B. The red numbers indicate the composite objects discussed in the present paper (photo: A. Dabasi and J. Kardos (HNM))

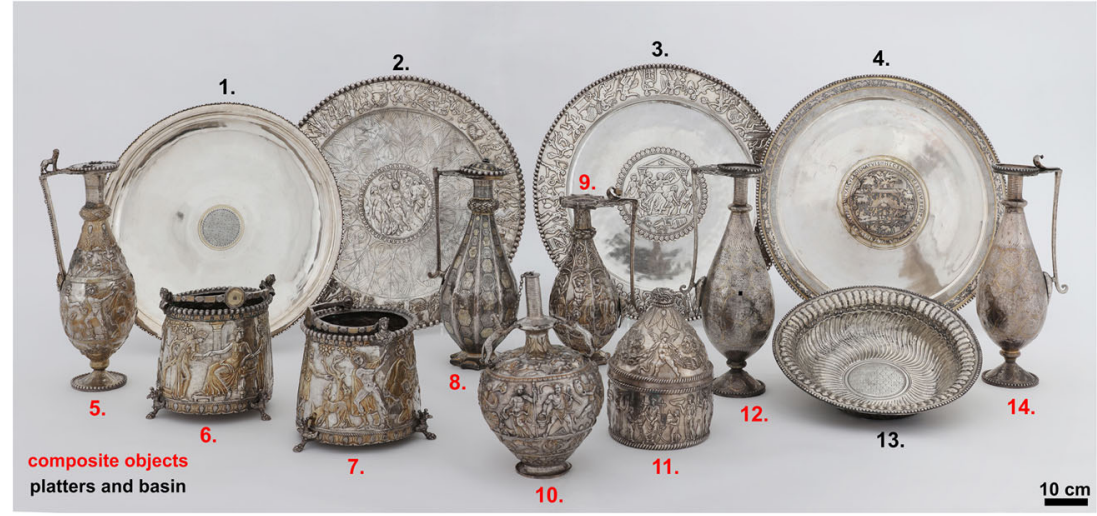

Ponting 2013; Sánchez and Lansing Maish 2014; Lang and Hughes 2016; Greiff 2017; Angelini et al. 2019; Arias et al. 2019), although other techniques were also used to determine the elemental composition of the objects, such as emission spectroscopy (Lang et al. 1977; Berthoud et al. 1988; Mango and Bennett 1994) and particle-induced X-ray emission spectroscopy (PIXE) (Tate and Troalen 2009; Doračić et al. 2015; Vulić et al. 2017).

Non-destructive handheld X-ray fluorescence spectrometry (hXRF) is one of the most popular elemental analytical methods in the fields of archaeology and cultural heritage (Shackley 2012; Frahm and Doonan 2013; Zlateva 2017), and it is often utilised in the analysis of archaeological and historical metal objects, particularly in the elemental analysis of precious metal objects (e.g. Karydas et al. 2004; Cesareo et al. 2008; Melcher et al. 2009; Parreira et al. 2009; Asderaki-Tzoumerkioti and Karydas 2011; Pardini et al. 2012; Mass and Matsen 2013; Zori and Tropper 2013; Lehmann et al. 2014; Živković et al. 2014; Mozgai et al. 2017; Mozgai et al. 2018; Horváth et al. 2019a; Szenthe et al. 2019; May 2020; Mozgai et al. 2020). XRF is a simultaneous, multi-element analytical method, whereby the concentrations of most elements of the periodic table ( $\mathrm{Z}=12-92$, from $\mathrm{Mg}$ to $\mathrm{U}$ ) can be determined (major, minor and trace elements).

The elemental analysis of silver objects is essential to understand the contemporaneous raw material use, alloying practice and manufacturing and decoration techniques. The major element content helps us to understand whether any conscious technological choice of alloys was applied for the different parts of the composite silver objects. The minor and trace element content can provide information about the used ore sources, raw materials and metallurgical techniques. Non-destructive analytical methods, such as handheld XRF, are particularly useful in the analysis of precious metal objects, where sampling is not or only limitedly allowed due to the high value of the objects. By using hXRF, the objects can be measured systematically at numerous points in situ in the museums, and semi-quantitative elemental information can be gained quickly. Moreover, sampling sites for more detailed analysis, e.g. quantitative elemental, lead isotopic and metallographic analysis, can be planned based on the hXRF measurements.

However, the hXRF method has some limitations, which must be taken into consideration during data evaluation. Because XRF is a surface analytical method, the measured concentrations represent the outer part (usually a few tens of microns) of the analysed objects. The signal comes from different depths, depending on the element and the matrix (Tate 1986; Mass and Matsen 2013). Metal objects can be chemically heterogeneous for several reasons, such as phase segregation in silver-copper alloys during manufacture; acid treatments after preparation (etching), which dissolve copper from the surface layers; polishing during and after manufacture; corrosion and tarnishing; remnants of gilding, etc. (Mass and Matsen 2013). Surface enrichment of silver alloys is a well-known phenomenon, during which base metals (e.g. copper and lead) are leached out from the surface, while silver and gold are enriched towards the surface (Hall 1961; Lejček et al. 2010), artificially exaggerating the silver and gold content at the expense of copper. Therefore, non-destructive surface analytical results, like hXRF data, may not represent the core metal composition. Surface enrichment can affect high-quality (>90 wt\%) silver objects as well, observed on silver coins (e.g. Beck et al. 2003; Beck et al. 2004; Caridi et al. 2013; Hrnjić et al. 2020; Hrnjić et al. in press). In order to reduce the effect of the surface enrichment, polishing or abrasion of a small area before XRF analysis is usually carried out (e.g. Hughes and Hall 1979; Lang et al. 1984; Lang 2002; Lang and Hughes 2016; Greiff 2017).

Metal samples taken from objects in the Seuso Treasure were previously analysed by ICP-OES and scanning electron microscopy (Mango and Bennett 1994). However, no analyses were performed on the Hippolytus Ewer, and only one metal sample was measured from the Toilet Casket, which is 
comprised of three parts. The ICP-OES results are sometimes inaccurate, as concentrations of gold were noticeably low in most cases. These limitations justify the utilisation of new, more detailed elemental analyses on the objects.

The aim of this study is to determine the elemental composition of the late Roman Seuso Treasure silver vessels using handheld XRF to classify the objects, to detect chemical differences between the objects, as well as chemical inhomogeneity within the objects, to determine the raw material (ore) used and to characterise the gilding and joining techniques. These results contribute to a more detailed reconstruction of late Roman craftsmanship, including silversmithing, manufacturing, alloying, decoration and assembling practices.

The Seuso objects were in good condition; thus, no additional surface cleaning (polishing or abrasion) was performed before this study's hXRF measurements. In return for the lack of cleaning, we performed measurements at several points on each part of the objects. Our approach differs from archaeometric studies performed on other Roman silver hoards, because those objects were usually only measured at a few points (1-20 points) per object (Lang et al. 1977; Hughes and Hall 1979; Lang et al. 1984; Berthoud et al. 1988; Feugère 1988; Hughes et al. 1989; Lang 2002; Cowell and Hook 2010; Hook and Callewaert 2013; Minning and Ponting 2013; Doračić et al. 2015; Lang and Hughes 2016; Greiff 2017; Vulić et al. 2017; Angelini et al. 2019; Arias et al. 2019), whereas our hXRF analysis eventuated a much larger data set ( 1600 points). Due to the high number of measurement points, surface cleaning was even more impossible, as the importance of the treasure meant that it was not appropriate to abrade the surface in order to expose the underlying metal over an area of about $3-8 \mathrm{~mm}$ in diameter $(7-50$ $\mathrm{mm}^{2}$ ), large enough to match the XRF beam, especially on the highly decorated, clearly visible sides.

Two of the platters (Seuso/Hunting Platter and Geometric Platter) manufactured from single casts were previously analysed by hXRF alongside two other late Roman platters (Ribbon Platter and Rosette Platter from the Sava River find), which revealed a slight variation in the concentration of silver and copper along the radii of the plates manufactured from high-quality silver (> $95 \mathrm{wt} \%$ Ag) (Mozgai et al. 2017). The two other large, silver platters (Meleager Platter and Achilles Platter) and the Basin, also made from high-quality silver, have a more homogeneous composition (Mozgai et al. 2020). In this paper, we focus on the composite objects (ewers, situlas, amphora and toilet casket), which are assembled from several parts, and examine, in detail, the chemical differences between the various parts of the objects. Furthermore, the hXRF data are compared with the previously published ICPOES data (Mango and Bennett 1994).

\section{Materials and methods}

\section{Materials: the composite silver objects of the Seuso Treasure}

Technological observations suggest that composite objects are composed of several parts (body, base, handle, lid, upper beaded rim, thumbpiece, feet) and were manufactured from different silver casts (Mango and Bennett 1994; Dági and Mráv 2019). They are classified into groups based on their shape and function (for parameters and decoration techniques of the objects, see Table 1).

The relief-decorated Amphora is embellished with Dionysiac motifs, animal fighting scenes and xenia images, and its shape and decoration suggest that it was used to serve wine. It was constructed from several parts: a body, a base, two panther-shaped handles and a stopper connected with a chain. The body was manufactured either with the lost-wax casting technique (like the Baratti amphora was, Arias et al. 2019) or was hammered out of a single piece of silver, with no visible joins or seams. The cast base was hammered, and a centring point for a lathe is visible on it. The handles were likely cast using the lost-wax technique.

The Animal Ewer is decorated with chased figures and a variety of geometric patterns. It may have belonged to a bathing set, or it may have been used to serve wine, like the Amphora was. The body and base were cast or raised from a single piece of silver by hammering, while the upper beaded rim was cast separately and soldered to the body. The lid, made from a piece of silver, shows traces of hammering. The handle was cast from a small bar of silver.

The Dionysiac Ewer is the smallest ewer in the Seuso Treasure. Based on its decoration with Dionysiac imagery (depicting the thiasos, the retinue of Dionysus), it was probably used to serve wine. The body, the base and the neck were cast or hammered from a single piece of silver. The octagonal rim was made separately by casting or hammering and was then soldered to the body. The handle was cast from a single bar of silver.

Geometric Ewers A and B are decorated with identical chased geometric motifs. The ewers likely formed a set with the Basin. The bodies were hammered out of individual pieces of silver, while the bases were made separately by hammering and were then mechanically attached to the bodies. The upper beaded rims were cast separately and were soldered to the bodies, whereas the handles were cast from small bars of silver.

The Hippolytus Ewer depicts scenes from Greek mythology (episodes from the Hippolytus story) and comprises a bathing set, along with two situlas. The body was cast or raised by hammering from a single silver piece. The base was cast and hammered from a separate piece of silver, after which it was mechanically attached and soldered to the body. The upper 
Table 1 Parameters and decoration techniques of the analysed composite silver objects from the Seuso Treasure. *repoussé technique: method of decorating metals in which parts of the design are raised in relief from the back or the inside of the object by means of hammers and punches. The name derives from the French word re-+ pousser meaning to push back (Untracht 1968; Maryon 1971; McCreight 1991)

\begin{tabular}{lllllll}
\hline Find name & Height $(\mathrm{cm})$ & Weight $(\mathrm{kg})$ & Capacity (litre) & Repoussé technique* & $\begin{array}{l}\text { Dot- } \\
\text { punching }\end{array}$ & Chasing Gilding Niello inlays \\
\hline
\end{tabular}

Ewers and amphora

\begin{tabular}{llll} 
Amphora & 38.5 & 2.5 & - \\
Animal Ewer & 51.0 & 3.98 & 4 \\
Dionysiac Ewer & 43.5 & 3.0 & 4 \\
Geometric Ewer A & 52.8 & 2.65 & 4 \\
Geometric Ewer B & 55.0 & 2.8 & 4 \\
Hippolytus Ewer & 57.3 & 4.05 & - \\
Cylindrical objects & & & \\
Hippolytus Situla A & 22.7 & 4.44 & - \\
Hippolytus Situla B & 22.9 & 4.48 & - \\
Toilet Casket & 32.0 & 2.05 & - \\
\hline
\end{tabular}

$\mathrm{X}$

$\mathrm{X}$

X

$\mathrm{X}$

$\mathrm{X}$

$\mathrm{X}$

$\begin{array}{ll}X & X \\ X & X \\ X & X \\ X & X \\ X & X \\ X & X \\ X & X \\ X & X \\ X & \end{array}$

\section{X}

$\mathrm{X}$

$\mathrm{X}$

X

$\mathrm{X}$

$\mathrm{X}$

$\mathrm{X}$

X

$\begin{array}{lll}X & X & X \\ X & X & X \\ X & X\end{array}$

beaded rim was cast separately and was then soldered to the body. The lid, handle and lion-shaped thumbpiece were made using the lost-wax technique.

The Hippolytus Situla $A$ and $B$ form a bathing set and are decorated with the same Greek mythological scenes as the Hippolytus Ewer is. The bodies were cast or hammered out of single sheets of silver. The beaded rims were cast separately and were then soldered to the bodies, while the three feet were cast using the lost-wax technique and were also soldered to the bodies. The handles were cast and riveted to the decorative busts, which were likewise soldered to the body.

The Toilet Casket was probably stored smaller ointment containers using in daily toiletries. Both the body and the lid were cast or manufactured by hammering from single sheets of silver. The interior pierced disc was produced from a hammered sheet of silver and contains seven pierced holes for flask storage.

The objects of the Seuso Treasure were examined, restored and conserved at the Institute of Archaeology at University College, London between April and December of 1989 (Bennett in Mango and Bennett 1994). Some of the objects were covered with calcareous encrustations, silver corrosion products and patches of green copper corrosion products. Furthermore, some parts of the objects were harshly cleaned and chemically polished during the period between the excavation and the restoration in 1989. Unfortunately, no information is known about this period. During the restoration in 1989, a $15 \%$ solution of ammonium thiosulphate and distilled water was used to remove silver corrosion products and calcareous encrustations from all visible surfaces. Green copper corrosion products were carefully removed with a $10 \%$ solution of formic acid and distilled water. After cleaning, each of the objects were washed several times in distilled water baths for 2-5 days. A thin layer of Paraloid B-72 was used to conserve the objects (Bennett in Mango and Bennett 1994).

\section{Methods}

After thorough macroscopic observation, the objects from the Seuso Treasure were systematically analysed by handheld Xray fluorescence spectrometry ( $\mathrm{hXRF}$ ) along a pre-designed grid at several points on each object (see Online Resource 1). The number of measurement points ranged from 2 to 70 points per part, depending on the size of the measured part of each object.

In this study, two hXRF instruments from different manufacturers were used: (i) a Thermo Scientific Niton X13t GOLDD+ (Waltham, Massachusetts, USA) and (ii) a SPECTRO xSORT Combi (Kleve, Germany) (see Table 2 for the analytical conditions). During the measurements, the concentrations of the following major, minor and trace elements were determined: $\mathrm{Ag}, \mathrm{Cu}, \mathrm{Au}, \mathrm{Pb}, \mathrm{Bi}, \mathrm{Sb}, \mathrm{Sn}, \mathrm{Zn}$ and Fe (see Online Resource 1 for the detection limits of each hXRF instrument). The built-in calibrations of each instrument were used for the measurements (Table 2). The Thermo Scientific Niton X13t GOLDD+ instrument measured Bi and Sb using the 'General Metals' calibration, whereas the 'Precious Metals' calibration was used for the rest of the elements. The quantitative evaluation was performed with the built-in fundamental parameters (FP) method, using Compton normalization. The results were normalised to $100 \%$, and no calibrations in data were applied. The precision and accuracy of the hXRF instruments were determined by separate measurements taken of a Roman silver spoon and on modern silver-copper alloys (see Online Resource 1 for details).

The XRF spectra were evaluated by using NITON Data Transfer Version NDT_REL_8.0.0 (Thermo Scientific Niton X13t GOLDD+) and XRF Analyzer Pro v.1.9. (SPECTRO xSORT Combi) software programs. The data points were 
Table 2 Comparison of the analytical conditions of the two handheld XRF instruments used for analysing the Seuso Treasure

\begin{tabular}{lll}
\hline Instrument & SPECTRO xSORT Combi & Thermo Scientific Niton Xl3t GOLDD+ \\
\hline Detector & Energy-dispersive SDD & Energy-dispersive LDD \\
X-ray tube & $50 \mathrm{kV}$; Rh-anode & $50 \mathrm{kV}$, Ag-anode \\
Built-in calibrations & 'Light Elements' & 'General Metals' and 'Precious Metals' \\
Spot size & $3 \mathrm{~mm}$ & 3 and $8 \mathrm{~mm}$ \\
Acquisition time & $60 \mathrm{~s}$ & $50 \mathrm{~s}$ and $40 \mathrm{~s}$ \\
\hline
\end{tabular}

plotted by using Microsoft Office Excel Professional Plus 2016 and CorelDraw Graphics Suite 2018 (v.20.1.0.708) software programs.

The relative error of the Thermo Scientific Niton X13t GOLDD+ instrument is less than $0.5 \%$ for silver, less than $5 \%$ for copper, less than $6 \%$ for gold, less than $10 \%$ for lead and less than $20 \%$ for bismuth. The relative error of the SPECTRO xSORT Combi instrument is better, namely less than $0.1 \%$ for silver, less than $0.5 \%$ for copper, less than $2 \%$ for gold, less than $5 \%$ for lead and less than $10 \%$ for bismuth. At some points (less than $7 \%$ of the total measurements), higher relative errors were calculated, but none is above $50 \%$. These points do not show a systematic distribution, and not related to an object or to a specific feature of the object (e.g. geometric problems).

For optimal measurements, the handheld XRF instrument requires ideal and reproducible surface geometries, such as flat surface that are parallel to the spectrometer head. The lack of suitable and reproducible geometries can cause an error of $0.5 \%$ or more, if the objects have complex geometries (e.g. ewers, vessels, statues) (Mass and Matsen 2013). Therefore, we aimed to measure surfaces that were as flat as possible, as well as to analyse the same locations on each object with each instrument.

We compared the performance of the two hXRF instruments based on the analysis of the composite objects of the Seuso Treasure and concluded that only the data measured by the same XRF instrument, under the same analytical conditions and using the same built-in calibration can be reliably compared (see Online Resource 1). As a result, hereafter we handle the data of the two instruments separately and compare the chemical compositions within these separate, independent data sets (according to Brand and Brand 2014).

\section{Results}

\section{Chemical composition of the composite objects of the Seuso Treasure}

In general, the objects were manufactured from high-quality silver alloyed with copper (79.6-99.4 wt\% Ag; 0.1-18.6 wt\%
$\mathrm{Cu}$ ) (Table 3; Figs. 2, 3 and 4). The gold content is around or below $1 \mathrm{wt} \%$ (except the Animal Ewer, discussion below) (Table 3; Figs. 2, 3 and 4). The lead content is usually below 1 wt\% (Table 3; Online Resource 2), and the bismuth content of the objects is heterogeneous, even within one object (Table 3; Figs. 2, 3 and 4). The tin, zinc and antimony contents are below the detection limit, with except for some parts of some of the objects (discussion below).

The various parts (base, body, handle, stopper) of the Amphora differ chemically from each other. The stopper contains the least amount of copper $(0.8-1.2 \mathrm{wt} \%)$, whereas the base contains the most (3.0-3.8 wt\%) (Fig. 2). The gold and lead contents are not homogeneous between the Amphora's parts. The bismuth content of the parts is very variable, ranging from 0 to 2600 ppm (Fig. 2; Online Resource 2).

The chemical composition of the various parts of the Animal Ewer is also different. The body and the base contain the least amount of copper (0.6-3.3 wt\%), whereas the upper beaded rim, lid and handle contain the most (1.0-7.3 wt\%) (Fig. 2). The gold and lead contents are generally below or around $1 \mathrm{wt} \%$. At several points, the gold content of the parts was elevated (>1 wt\%) (discussion below) (Fig. 2). The bismuth content of the parts is homogeneous (100-1400 ppm) (Fig. 2). In the upper beaded rim and the handle, 0.5-0.8 wt $\%$ tin was detected. The chemical composition of the body and the base is identical, but the handle, upper beaded rim and lid were manufactured from silver alloys of different compositions.

The chemical composition of the various parts of the Dionysiac Ewer is different. The base and the body have the lowest copper content (1.1-1.8 wt\%), whereas the handle and the thumbpiece have the highest (2.7-4.3 wt\%) (Fig. 2). The body and the base have the same chemical composition; however, the thumbpiece, handle and upper octagonal rim were made from different silver alloys. The silver and copper contents of the upper octagonal rim fall between the composition of the thumbpiece and handle and the base and body, respectively. The gold and lead contents are below $1 \mathrm{wt} \%$ (Fig. 2; Online Resource 2). The bismuth content of the Dionysiac Ewer is the highest (1200-3200 ppm) of all the Seuso objects (Fig. 2). In the thumbpiece and handle, 0.5-0.6 wt\% zinc was detected. 
Table 3 Chemical composition of the composite objects of the Seuso Treasure. $\mathrm{Ag}, \mathrm{Cu}, \mathrm{Au}, \mathrm{Pb}$ are given in wt\%, $\mathrm{Bi}$ is given in ppm. $\mathrm{N}=$ measured using Niton X13t GOLDD+ hXRF; $\mathrm{S}=$ measured using
SPECTRO xSORT Combi hXRF. The minimum-maximum values are given. The $\mathrm{Au} / \mathrm{Ag}$ and $\mathrm{Bi} / \mathrm{Pb}$ ratios were calculated for each measurement points and the minimum-maximum values are given as well

\begin{tabular}{|c|c|c|c|c|c|c|c|c|c|}
\hline & Instrument & No. of analyses & $\mathrm{Ag}$ & $\mathrm{Cu}$ & $\mathrm{Au}$ & $\mathrm{Pb}$ & $\mathrm{Bi}$ & $\mathrm{Au} / \mathrm{Ag}$ & $\mathrm{Bi} / \mathrm{Pb}$ \\
\hline \multicolumn{10}{|l|}{ Amphora } \\
\hline \multirow[t]{2}{*}{ Base } & $\mathrm{N}$ & 8 & $93.7-94.9$ & $3.3-3.8$ & $1.0-1.2$ & $0.6-0.9$ & $1400-1900$ & $0.011-0.013$ & $0.21-0.24$ \\
\hline & $\mathrm{S}$ & 4 & $94.0-94.8$ & $3.0-3.6$ & $0.9-1.0$ & $0.6-0.9$ & $1100-1400$ & $0.010-0.011$ & $0.16-0.18$ \\
\hline \multirow[t]{2}{*}{ Body } & $\mathrm{N}$ & 54 & $96.1-98.0$ & $0.5-1.9$ & $0.6-1.2$ & $0.4-1.5$ & $0-500$ & $0.006-0.013$ & $0-0.08$ \\
\hline & $\mathrm{S}$ & 27 & $96.2-97.7$ & $1.1-1.8$ & $0.5-0.8$ & $0.6-1.0$ & $0-200$ & $0.005-0.008$ & $0-0.03$ \\
\hline \multirow[t]{2}{*}{ Handle } & $\mathrm{N}$ & 4 & $95.8-96.2$ & $2.3-2.6$ & $0.4-0.5$ & $1.0-1.1$ & $200-300$ & 0.005 & $0.01-0.02$ \\
\hline & $\mathrm{S}$ & 4 & $95.5-95.9$ & $2.3-2.5$ & $0.4-0.5$ & 1.1 & $100-200$ & $0.004-0.005$ & $0.01-0.02$ \\
\hline \multirow[t]{2}{*}{ Stopper } & $\mathrm{N}$ & 2 & $97.7-98.1$ & $1.1-1.2$ & $0.3-0.5$ & 0.2 & $2000-2600$ & $0.004-0.006$ & $0.95-1.23$ \\
\hline & $\mathrm{S}$ & 2 & $98.2-98.4$ & 0.8 & 0.3 & $0.1-0.2$ & $1500-1600$ & 0.003 & $0.99-1.00$ \\
\hline \multicolumn{10}{|l|}{ Animal Ewer } \\
\hline \multirow[t]{2}{*}{ Body } & $\mathrm{N}$ & 64 & 94.9-97.9 & $0.8-3.3$ & $0.9-2.4$ & $0.2-0.9$ & $400-1000$ & $0.009-0.025$ & $0.09-0.40$ \\
\hline & $\mathrm{S}$ & 31 & $94.2-97.9$ & $0.6-2.2$ & $0.8-1.9$ & $0.1-0.9$ & $100-700$ & $0.008-0.020$ & $0.06-0.25$ \\
\hline \multirow[t]{2}{*}{ Base } & $\mathrm{N}$ & 11 & $96.4-98.3$ & $0.5-1.7$ & $0.5-1.6$ & $0.2-0.3$ & $500-900$ & $0.005-0.017$ & $0.26-0.34$ \\
\hline & $\mathrm{S}$ & 4 & 95.9-97.0 & $1.3-1.6$ & $0.9-1.0$ & $0.2-0.3$ & $400-500$ & 0.010 & $0.16-0.21$ \\
\hline \multirow[t]{2}{*}{ Handle } & $\mathrm{N}$ & 7 & $92.9-94.6$ & $3.2-4.7$ & $0.7-1.7$ & $0.4-0.7$ & $900-1100$ & $0.008-0.018$ & $0.15-0.23$ \\
\hline & $\mathrm{S}$ & 4 & $94.0-94.5$ & $3.4-4.1$ & $0.8-1.1$ & $0.4-0.5$ & $600-900$ & $0.009-0.011$ & $0.16-0.17$ \\
\hline \multirow[t]{2}{*}{ Upper beaded rim } & $\mathrm{N}$ & 5 & $93.7-95.4$ & $2.4-4.0$ & $1.0-1.1$ & $0.3-0.5$ & $700-1400$ & $0.011-0.012$ & $0.21-0.31$ \\
\hline & $\mathrm{S}$ & 3 & $94.6-95.0$ & $2.6-3.2$ & $1.2-1.4$ & $0.2-0.4$ & $500-600$ & $0.012-0.015$ & $0.15-0.22$ \\
\hline \multirow[t]{2}{*}{ Lid } & $\mathrm{N}$ & 10 & $90.5-96.7$ & $1.0-7.3$ & $0.4-1.4$ & $0.3-0.9$ & $300-1100$ & $0.004-0.015$ & $0.04-0.17$ \\
\hline & $\mathrm{S}$ & 3 & $93.2-93.8$ & $3.3-3.7$ & $0.7-0.8$ & 0.7 & $700-800$ & $0.008-0.009$ & 0.11 \\
\hline \multicolumn{10}{|l|}{ Dionysiac Ewer } \\
\hline \multirow[t]{2}{*}{ Body } & $\mathrm{N}$ & 61 & $96.6-98.0$ & $1.1-1.8$ & $0.4-1.2$ & $0.1-0.3$ & $1400-2400$ & $0.004-0.013$ & $0.54-1.64$ \\
\hline & $\mathrm{S}$ & 14 & $96.4-97.9$ & $1.3-1.6$ & $0.3-0.5$ & 0.1 & $1200-1700$ & $0.003-0.005$ & $1.13-2.21$ \\
\hline \multirow[t]{2}{*}{ Base } & $\mathrm{N}$ & 8 & $97.2-97.8$ & $1.3-1.8$ & $0.4-0.5$ & $0.1-0.2$ & $1600-2000$ & $0.004-0.005$ & $0.86-1.46$ \\
\hline & $\mathrm{S}$ & 7 & $97.5-97.9$ & $1.2-1.5$ & $0.3-0.4$ & 0.1 & $1200-1300$ & 0.004 & $0.87-2.28$ \\
\hline Thumbpiece & $\mathrm{N}$ & 3 & $94.0-95.0$ & $3.2-4.2$ & $0.5-0.6$ & $0.2-0.3$ & $2800-3200$ & $0.005-0.007$ & $1.05-1.14$ \\
\hline \multirow[t]{2}{*}{ Handle } & $\mathrm{N}$ & 6 & $93.2-95.6$ & $2.7-4.3$ & $0.5-0.7$ & $0.2-1.1$ & $2500-3200$ & $0.005-0.007$ & $0.29-1.20$ \\
\hline & $\mathrm{S}$ & 2 & $91.2-94.7$ & $3.8-4.1$ & $0.4-0.5$ & $0.2-0.5$ & $2100-2200$ & $0.004-0.006$ & $0.44-1.26$ \\
\hline \multirow[t]{2}{*}{ Upper octagonal rim } & $\mathrm{N}$ & 6 & $95.6-96.4$ & $2.3-2.6$ & $0.5-0.6$ & $0.1-0.6$ & $2800-3200$ & $0.005-0.006$ & $0.52-2.31$ \\
\hline & $\mathrm{S}$ & 5 & $95.8-96.4$ & $2.3-2.5$ & $0.5-0.6$ & $0.1-0.4$ & $2100-2500$ & $0.005-0.006$ & $0.57-2.62$ \\
\hline \multicolumn{10}{|l|}{ Geometric Ewer A } \\
\hline \multirow[t]{2}{*}{ Body } & $\mathrm{N}$ & 70 & $93.9-97.8$ & $0.9-2.9$ & $0.7-1.1$ & $0.5-1.1$ & $900-1400$ & $0.008-0.012$ & $0.10-0.19$ \\
\hline & $\mathrm{S}$ & 30 & $96.3-97.9$ & $0.9-1.6$ & $0.7-0.9$ & $0.4-0.7$ & $500-1000$ & $0.007-0.009$ & $0.09-0.15$ \\
\hline \multirow[t]{2}{*}{ Base } & $\mathrm{N}$ & 14 & $94.5-97.1$ & $1.4-4.1$ & $0.7-1.1$ & $0.2-0.5$ & $500-1100$ & $0.008-0.011$ & $0.16-0.25$ \\
\hline & $\mathrm{S}$ & 9 & $94.3-96.2$ & $1.1-3.7$ & $0.8-1.1$ & $0.1-0.6$ & $100-700$ & $0.008-0.011$ & $0.04-0.14$ \\
\hline \multirow[t]{2}{*}{ Handle } & $\mathrm{N}$ & 7 & $92.3-94.7$ & $3.8-6.1$ & 0.8 & $0.6-0.8$ & $1000-1200$ & $0.008-0.009$ & $0.13-0.19$ \\
\hline & $\mathrm{S}$ & 5 & $93.0-94.8$ & $3.5-5.2$ & $0.7-0.8$ & $0.7-0.8$ & $800-1000$ & $0.007-0.009$ & $0.10-0.14$ \\
\hline Upper beaded rim & $\mathrm{N}$ & 4 & $93.0-95.2$ & $3.7-5.8$ & $0.8-0.9$ & $0.3-0.6$ & $500-900$ & $0.008-0.010$ & $0.17-0.21$ \\
\hline & $\mathrm{S}$ & 4 & $91.6-93.0$ & $4.5-6.5$ & $0.7-1.0$ & $0.2-0.6$ & $400-700$ & $0.008-0.010$ & $0.11-0.23$ \\
\hline Geometric Ewer B & & & & & & & & & \\
\hline Body & $\mathrm{N}$ & 62 & $95.2-97.1$ & $1.6-3.2$ & $0.8-1.1$ & $0.2-0.4$ & $600-1000$ & $0.009-0.011$ & $0.17-0.21$ \\
\hline & $\mathrm{S}$ & 16 & $95.4-96.4$ & $1.9-2.5$ & $0.7-1.1$ & $0.2-0.3$ & $400-700$ & $0.008-0.011$ & $0.14-0.19$ \\
\hline Base & $\mathrm{N}$ & 11 & $79.6-94.0$ & $4.5-18.6$ & $0.8-1.1$ & $0.4-0.5$ & $700-900$ & $0.009-0.011$ & $0.17-0.31$ \\
\hline & $\mathrm{S}$ & 7 & $84.9-93.5$ & $4.5-10.9$ & $0.7-1.0$ & $0.3-0.5$ & $500-800$ & $0.008-0.011$ & $0.15-0.27$ \\
\hline Handle & $\mathrm{N}$ & 11 & $92.4-94.6$ & $3.7-5.9$ & $0.7-0.9$ & $0.6-0.8$ & $800-1100$ & $0.008-0.009$ & $0.11-0.15$ \\
\hline & $\mathrm{S}$ & 5 & $93.5-94.2$ & $3.6-4.8$ & $0.7-0.8$ & 0.8 & $700-900$ & $0.007-0.009$ & $0.09-0.11$ \\
\hline Upper beaded rim & $\mathrm{N}$ & 5 & $90.2-95.6$ & $2.0-7.1$ & $0.7-1.0$ & $0.6-1.3$ & $500-1100$ & $0.008-0.010$ & $0.04-0.17$ \\
\hline
\end{tabular}


Table 3 (continued)

\begin{tabular}{|c|c|c|c|c|c|c|c|c|c|}
\hline & Instrument & No. of analyses & $\mathrm{Ag}$ & $\mathrm{Cu}$ & $\mathrm{Au}$ & $\mathrm{Pb}$ & $\mathrm{Bi}$ & $\mathrm{Au} / \mathrm{Ag}$ & $\mathrm{Bi} / \mathrm{Pb}$ \\
\hline & $\mathrm{S}$ & 2 & $89.6-95.5$ & $1.4-4.6$ & $0.8-1.0$ & $0.6-0.9$ & $0-400$ & $0.009-0.011$ & $0.009-0.011$ \\
\hline Thumbpiece & $\mathrm{N}$ & 3 & $93.5-94.8$ & $3.4-4.6$ & $0.8-0.9$ & $0.7-0.8$ & $1000-1200$ & $0.008-0.009$ & $0-0.07$ \\
\hline \multicolumn{10}{|l|}{ Hippolytus Ewer } \\
\hline \multirow[t]{2}{*}{ Body } & $\mathrm{N}$ & 32 & $94.4-96.8$ & $1.8-4.1$ & $0.6-1.0$ & $0.4-0.6$ & $900-1500$ & $0.007-0.011$ & $0.21-0.28$ \\
\hline & $\mathrm{S}$ & 15 & $96.2-96.8$ & $1.6-2.1$ & $0.6-0.8$ & $0.4-0.5$ & $700-1000$ & $0.007-0.008$ & $0.16-0.23$ \\
\hline \multirow[t]{2}{*}{ Base } & $\mathrm{N}$ & 15 & $95.7-98.4$ & $0.8-2.9$ & $0.5-1.0$ & $0.2-0.4$ & $700-2600$ & $0.005-0.010$ & $0.19-1.09$ \\
\hline & $\mathrm{S}$ & 8 & $94.3-97.5$ & $1.3-2.8$ & $0.5-1.0$ & $0.1-0.4$ & $500-1200$ & $0.005-0.010$ & $0.16-0.98$ \\
\hline \multirow[t]{2}{*}{ Lid } & $\mathrm{N}$ & 8 & $91.4-95.1$ & $3.6-6.9$ & $0.6-1.0$ & $0.5-0.6$ & $500-900$ & $0.006-0.010$ & $0.09-0.16$ \\
\hline & $\mathrm{S}$ & 4 & $92.2-94.2$ & $3.4-6.2$ & $0.5-0.6$ & $0.4-0.6$ & $400-600$ & $0.006-0.007$ & $0.08-0.11$ \\
\hline \multirow[t]{2}{*}{ Handle } & $\mathrm{N}$ & 9 & $93.9-97.1$ & $1.6-5.0$ & $0.6-1.1$ & $0.3-1.1$ & $700-2000$ & $0.007-0.011$ & $0.11-0.56$ \\
\hline & $\mathrm{S}$ & 2 & $94.8-96.2$ & $2.3-3.4$ & $0.8-0.9$ & $0.3-0.4$ & $400-1300$ & 0.009 & $0.12-0.40$ \\
\hline \multirow[t]{2}{*}{ Upper beaded rim } & $\mathrm{N}$ & 8 & $94.0-97.5$ & $1.5-3.2$ & $0.5-0.9$ & $0.3-1.4$ & $1500-2300$ & $0.005-0.010$ & $0.16-0.62$ \\
\hline & $\mathrm{S}$ & 4 & $95.2-97.0$ & $1.7-3.2$ & 0.5 & $0.2-0.6$ & $1400-1700$ & $0.005-0.006$ & $0.30-0.72$ \\
\hline \multicolumn{10}{|l|}{ Hippolytus Situla A } \\
\hline \multirow[t]{2}{*}{ Handle } & $\mathrm{N}$ & 9 & $95.6-97.2$ & $1.8-2.7$ & $0.6-0.9$ & $0.4-0.7$ & $400-900$ & $0.007-0.009$ & $0.10-0.16$ \\
\hline & $\mathrm{S}$ & 4 & $96.6-97.1$ & $1.8-2.0$ & 0.6 & $0.2-0.5$ & $200-500$ & $0.006-0.007$ & $0.06-0.10$ \\
\hline \multirow[t]{2}{*}{ Feet } & $\mathrm{N}$ & 8 & $95.4-97.6$ & $0.8-2.6$ & $0.9-1.1$ & $0.3-0.8$ & $400-1100$ & $0.010-0.011$ & $0.08-0.29$ \\
\hline & $\mathrm{S}$ & 2 & $95.2-96.2$ & $2.1-2.6$ & $0.8-0.9$ & $0.4-0.7$ & $600-700$ & $0.008-0.010$ & $0.10-0.14$ \\
\hline \multirow[t]{2}{*}{ Body } & $\mathrm{N}$ & 32 & $96.2-98.2$ & $0.6-2.8$ & $0.5-0.9$ & $0.1-0.3$ & $200-900$ & $0.005-0.010$ & $0.07-1.47$ \\
\hline & $\mathrm{S}$ & 21 & $95.7-97.2$ & $2.1-2.6$ & $0.4-0.6$ & $0.1-0.2$ & $0-200$ & $0.005-0.006$ & $0-0.12$ \\
\hline \multirow[t]{2}{*}{ Upper beaded rim } & $\mathrm{N}$ & 5 & $98.9-99.2$ & $0.4-0.6$ & $0.3-0.4$ & $0-0.1$ & $0-1400$ & $0.003-0.004$ & $0-3.20$ \\
\hline & $\mathrm{S}$ & 4 & $95.3-99.0$ & $0.3-0.5$ & 0.3 & $0-0.04$ & $400-800$ & 0.003 & $0-6.28$ \\
\hline \multicolumn{10}{|l|}{ Hippolytus Situla B } \\
\hline \multirow[t]{2}{*}{ Handle } & $\mathrm{N}$ & 11 & $96.6-97.7$ & $1.2-2.1$ & $0.6-0.8$ & $0.3-0.5$ & $300-800$ & $0.006-0.008$ & $0.08-0.30$ \\
\hline & $\mathrm{S}$ & 4 & 97.3 & $1.6-1.7$ & $0.5-0.6$ & 0.3 & $0-300$ & $0.005-0.006$ & $0-0.10$ \\
\hline \multirow[t]{2}{*}{ Feet } & $\mathrm{N}$ & 8 & $94.6-97.3$ & $1.1-2.9$ & $0.7-1.1$ & $0.2-1.3$ & $700-1200$ & $0.008-0.012$ & $0.09-0.33$ \\
\hline & $\mathrm{S}$ & 2 & $95.2-95.4$ & $2.5-2.7$ & 0.8 & $0.4-0.5$ & 700 & $0.008-0.009$ & $0.14-0.17$ \\
\hline \multirow[t]{2}{*}{ Body } & $\mathrm{N}$ & 33 & $95.6-97.5$ & $1.7-3.2$ & $0.5-0.9$ & $0.3-0.5$ & $200-500$ & $0.006-0.010$ & $0.07-0.12$ \\
\hline & $\mathrm{S}$ & 22 & $92.5-97.4$ & $1.7-2.7$ & $0.5-1.0$ & $0.2-0.5$ & $100-400$ & $0.005-0.011$ & $0.02-0.11$ \\
\hline \multirow[t]{2}{*}{ Upper beaded rim } & $\mathrm{N}$ & 8 & $98.6-99.3$ & $0.1-0.8$ & $0.3-0.5$ & $0-0.4$ & $500-2000$ & $0.003-0.005$ & $0.18-2.60$ \\
\hline & $\mathrm{S}$ & 6 & $98.7-99.4$ & $0.1-0.5$ & $0.2-0.5$ & $0-0.01$ & $0-600$ & $0.002-0.005$ & $0-6.41$ \\
\hline \multicolumn{10}{|l|}{ Toilet Casket } \\
\hline \multirow[t]{2}{*}{ Lid } & $\mathrm{N}$ & 55 & $94.8-96.6$ & $2.0-3.7$ & $0.6-1.2$ & $0.3-0.5$ & $600-1300$ & $0.006-0.013$ & $0.14-0.33$ \\
\hline & $\mathrm{S}$ & 23 & $94.8-96.7$ & $1.9-3.5$ & $0.7-1.2$ & $0.3-0.5$ & $500-1000$ & $0.007-0.013$ & $0.13-0.22$ \\
\hline \multirow[t]{2}{*}{ Base } & $\mathrm{N}$ & 49 & $94.9-97.5$ & $1.2-3.6$ & $0.8-1.2$ & $0.2-0.5$ & $400-900$ & $0.009-0.013$ & $0.10-0.20$ \\
\hline & $\mathrm{S}$ & 24 & $95.0-96.9$ & $1.0-3.4$ & $0.8-1.0$ & $0.2-0.5$ & $100-500$ & $0.009-0.011$ & $0.03-0.11$ \\
\hline \multirow[t]{2}{*}{ Pierced disc } & $\mathrm{N}$ & 12 & $93.4-93.8$ & $4.3-4.7$ & 0.8 & 0.7 & $1300-1500$ & 0.009 & $0.19-0.21$ \\
\hline & $\mathrm{S}$ & 6 & $91.8-94.1$ & $3.9-4.5$ & $0.7-0.8$ & $0.6-0.8$ & $1000-1200$ & 0.008 & $0.14-0.16$ \\
\hline
\end{tabular}

The two Geometric Ewers (A and B) have a similar chemical composition. The bodies contain the least amount of copper (0.9-3.2 wt\%), whereas the base of Geometric Ewer B shows an elevated amount of copper (4.5-18.6 wt\%), with a very heterogeneous distribution. The base of Geometric Ewer A exhibits a lower concentration of copper (between the composition of the body and the upper beaded rim and handle) (Fig. 3). The gold and lead contents are below $1 \mathrm{wt} \%$ (Fig. 3; Online Resource 2). The bismuth content is homogeneous
(Fig. 3). The chemical composition of the various parts of each ewer (body, handle, base, thumbpiece, upper beaded rim) indicates that they were manufactured from silver alloys of different compositions.

Based on the observed variation in the chemical composition of the different parts (lid, body, base, handle, upper beaded rim) of the Hippolytus Ewer, they were manufactured from different silver alloys. The lid has the highest copper content (3.4-6.9 wt\%), whereas the base has the lowest 


\section{Amphora}

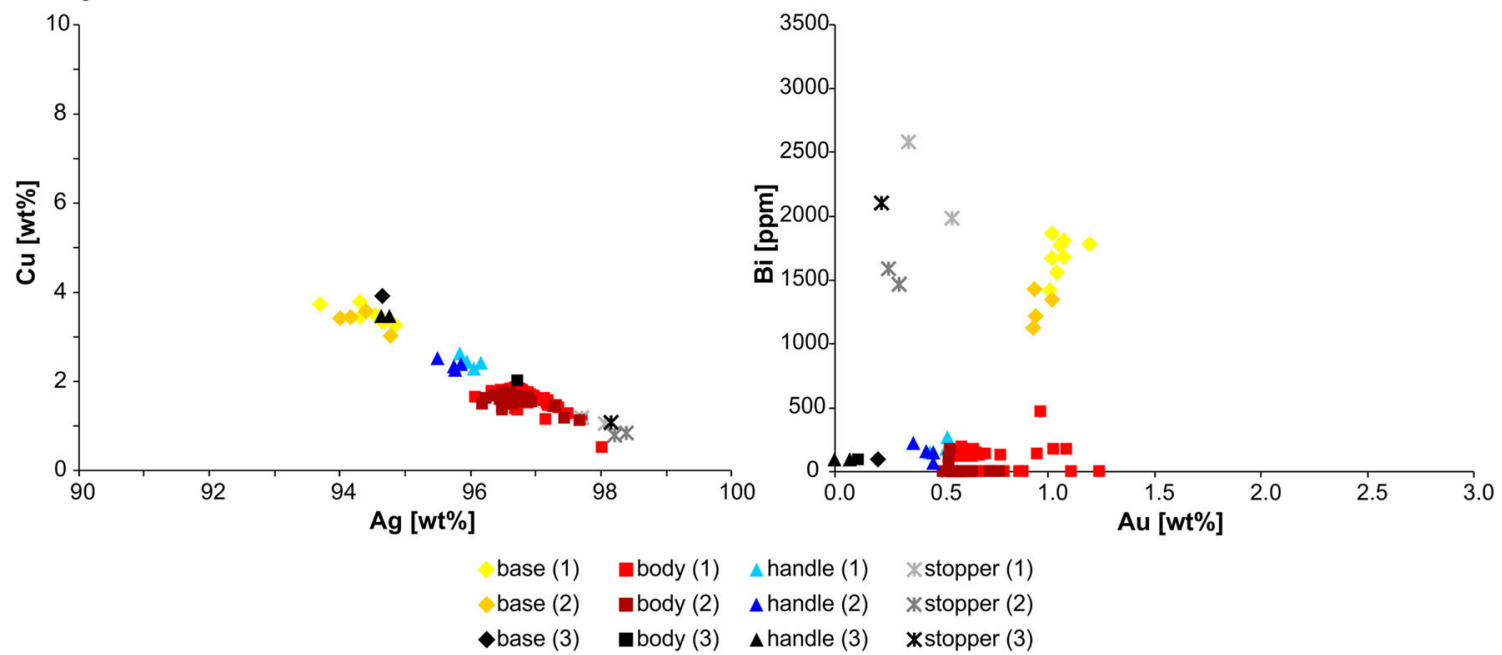

Animal Ewer

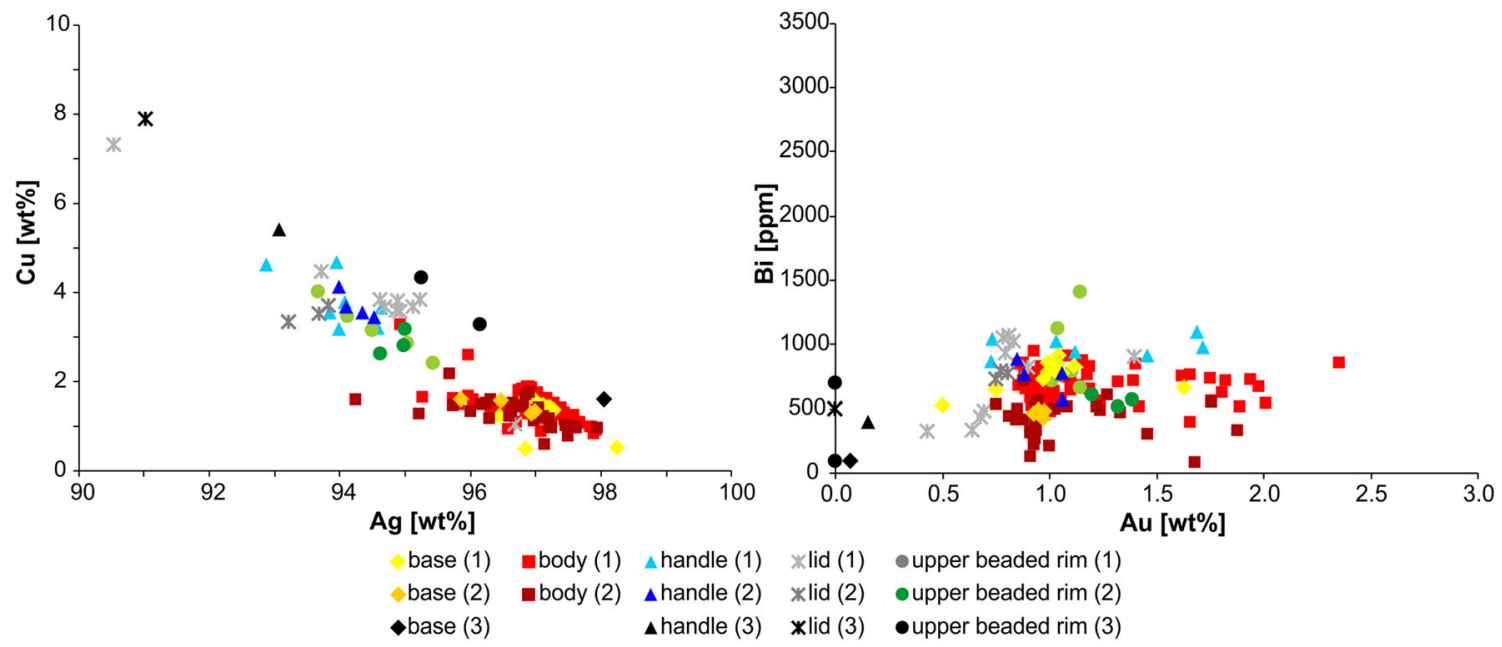

Dionysiac Ewer
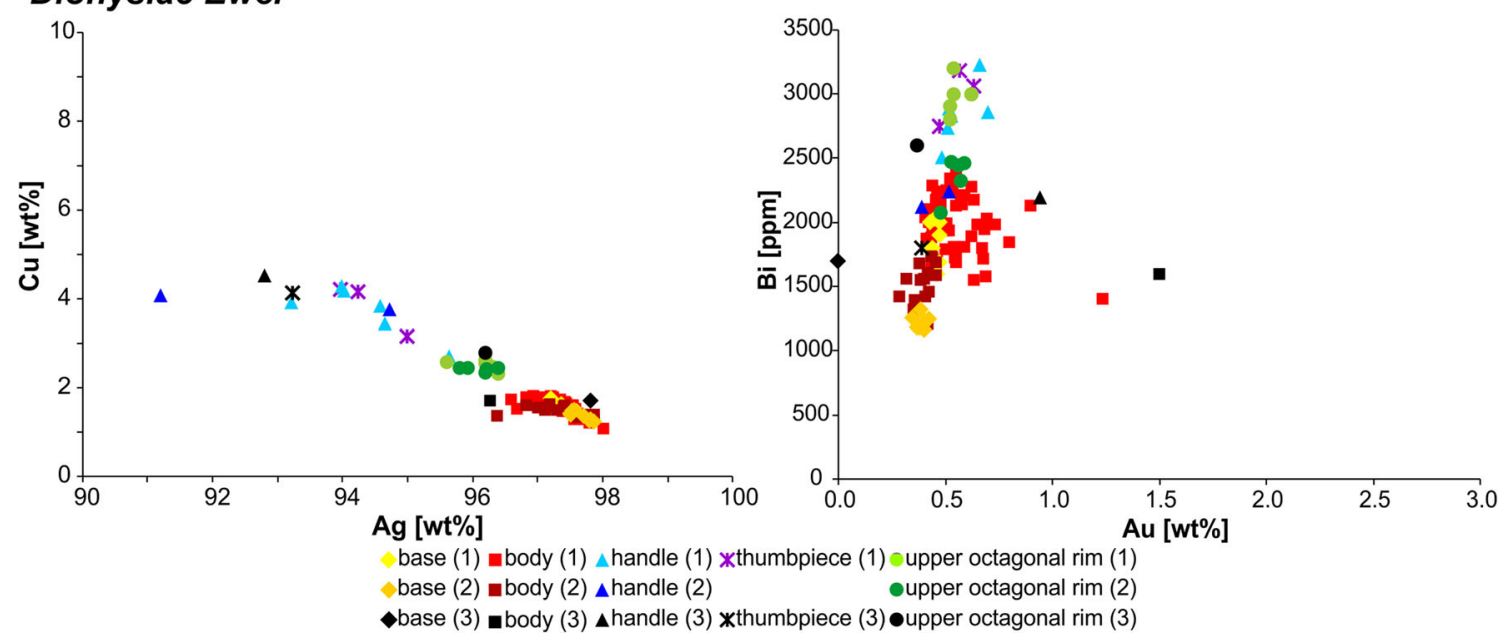

Fig. 2 Silver vs. copper and gold vs. bismuth content of the Amphora, the Dionysiac and the Animal Ewers based on the hXRF measurements, Niton X13t GOLDD+; 2: SPECTRO xSORT Combi; 3: ICP-OES (Mango and Bennett 1994) previous ICP-OES data are shown for comparison. Measured with 1:

(0.8-2.9 wt\%) (Fig. 3). Although the gold and lead contents are constant and fall below $1 \mathrm{wt} \%$, the upper beaded rim and handle contain a slightly higher percentage of lead $(0.2-1.4$ wt\%) (Fig. 3; Online Resource 2). The bismuth content is 


\section{Geometric Ewer A}

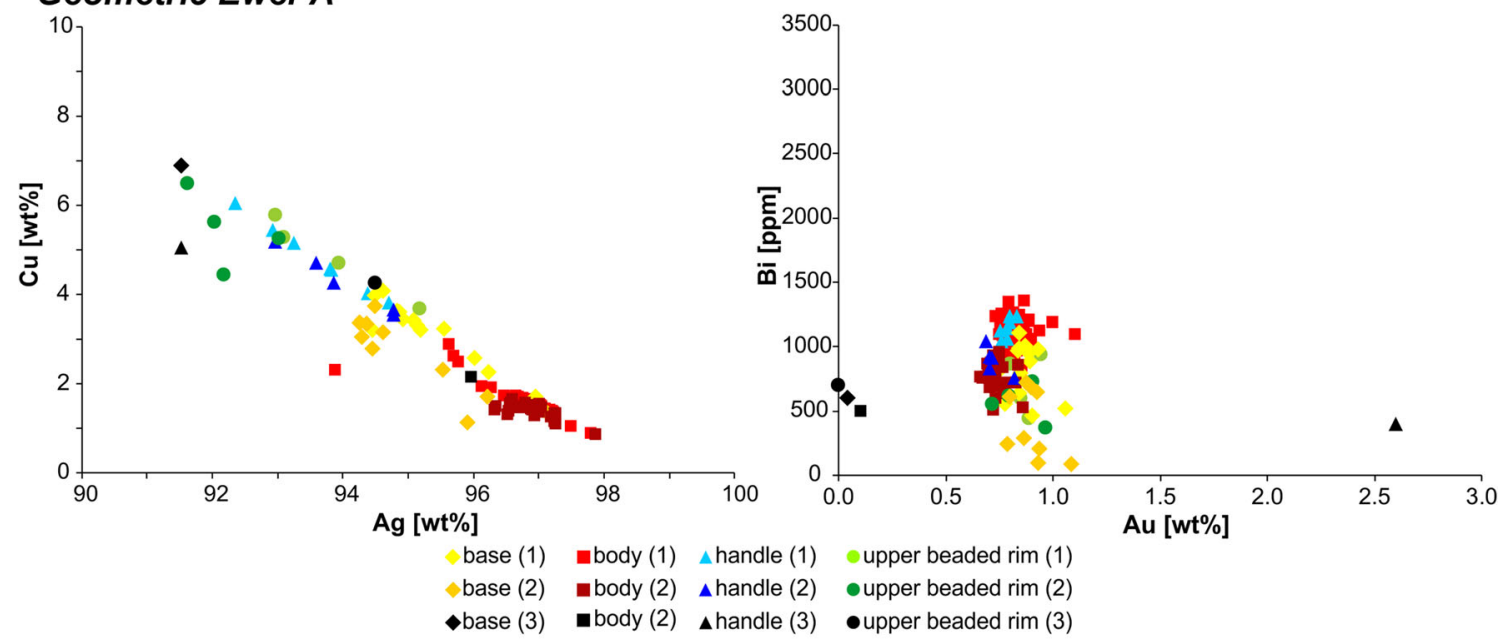

Geometric Ewer B

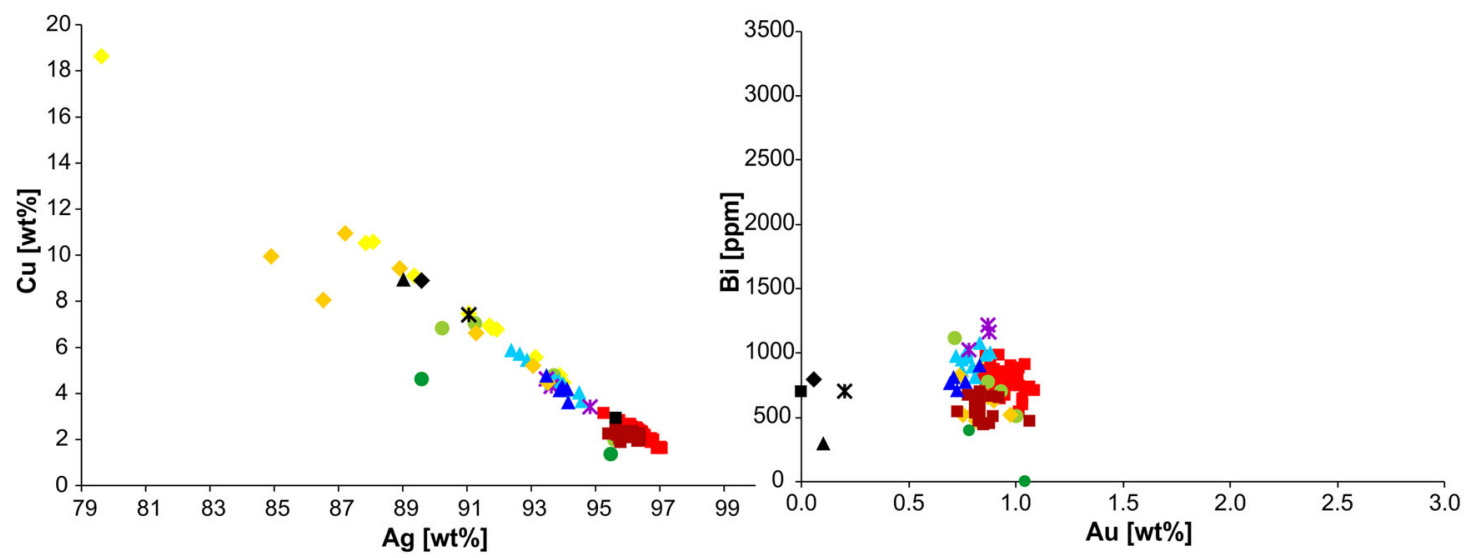

base (1) घbody (1) $\Delta$ handle (1) xthumbpiece (1) oupper beaded rim (1)

base (2) body (2) $\Delta$ handle (2)

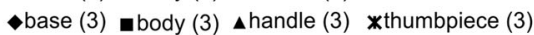

Hippolytus Ewer

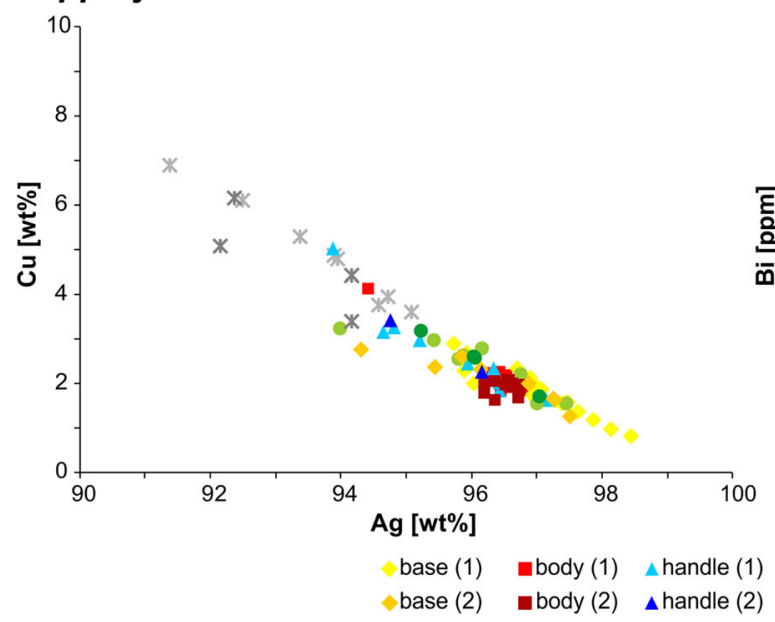

Fig. 3 Silver vs. copper and gold vs. bismuth content of the Hippolytus and the Geometric Ewers based on the hXRF measurements, previous ICP-OES data are shown for comparison. Measured with 1: Niton X13t

much more heterogeneous than the gold and lead content of the parts. The bismuth content of the body, lid and handle is

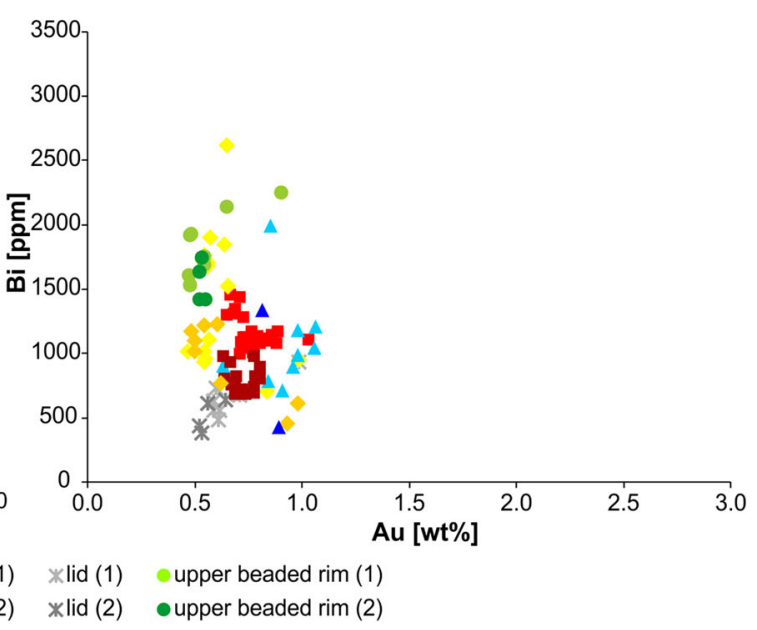

GOLDD+; 2: SPECTRO xSORT Combi; 3: ICP-OES (Mango and Bennett 1994)

400-1500 ppm, and the upper beaded rim and part of the base exhibit higher concentrations (500-2600 ppm) (Fig. 3). 


\section{Hippolytus Situla A}

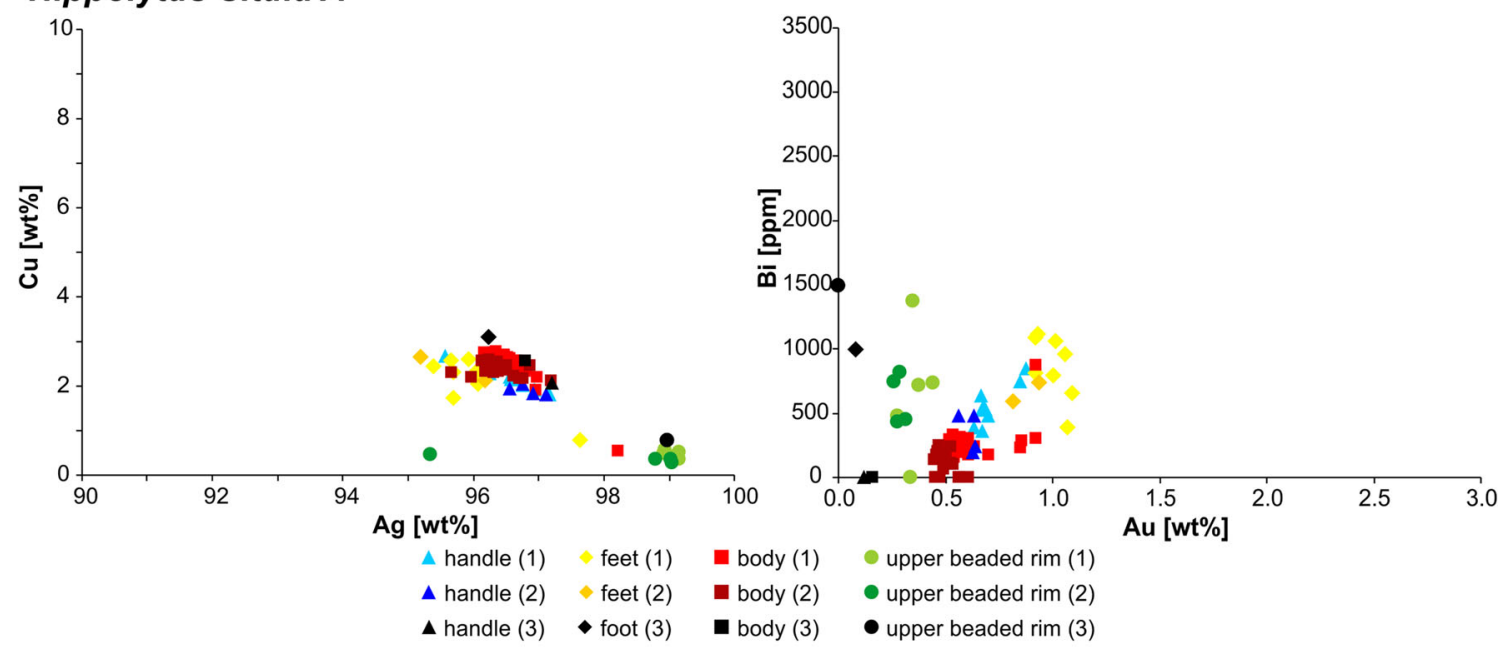

Hippolytus Situla B

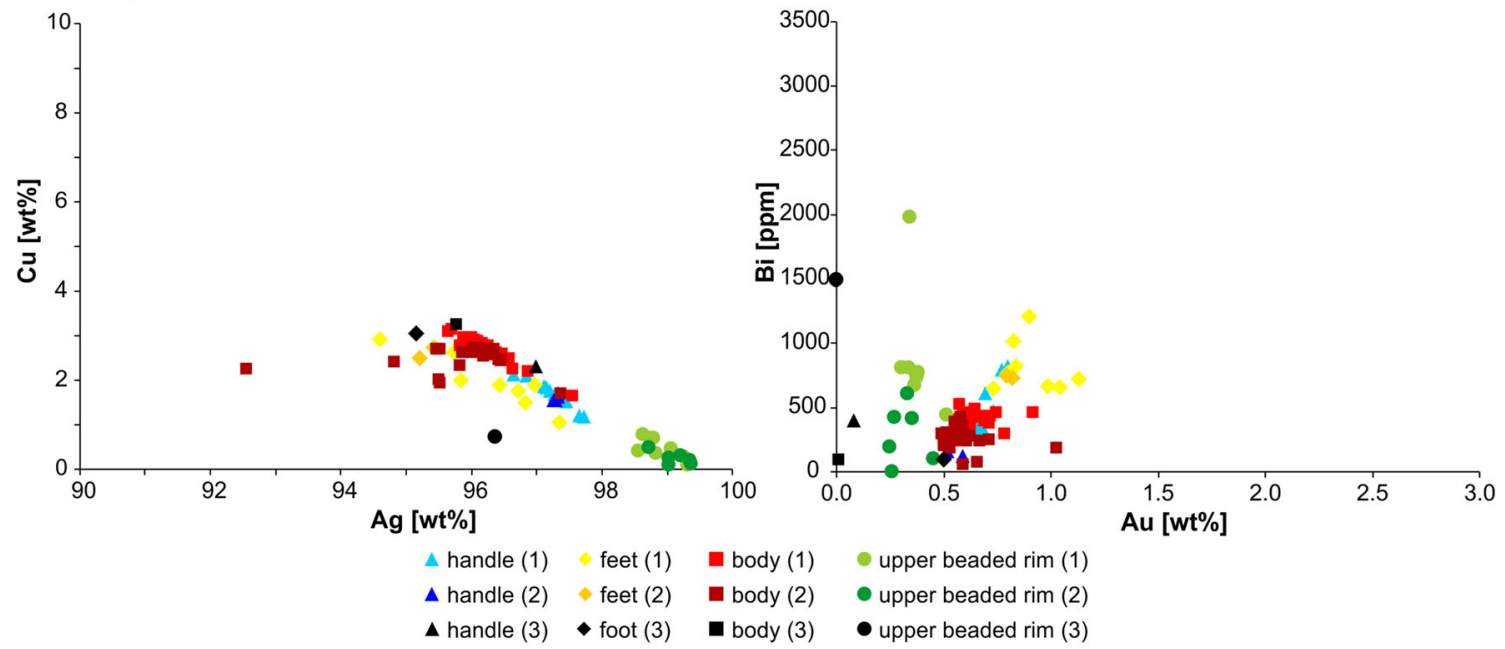

Toilet Casket
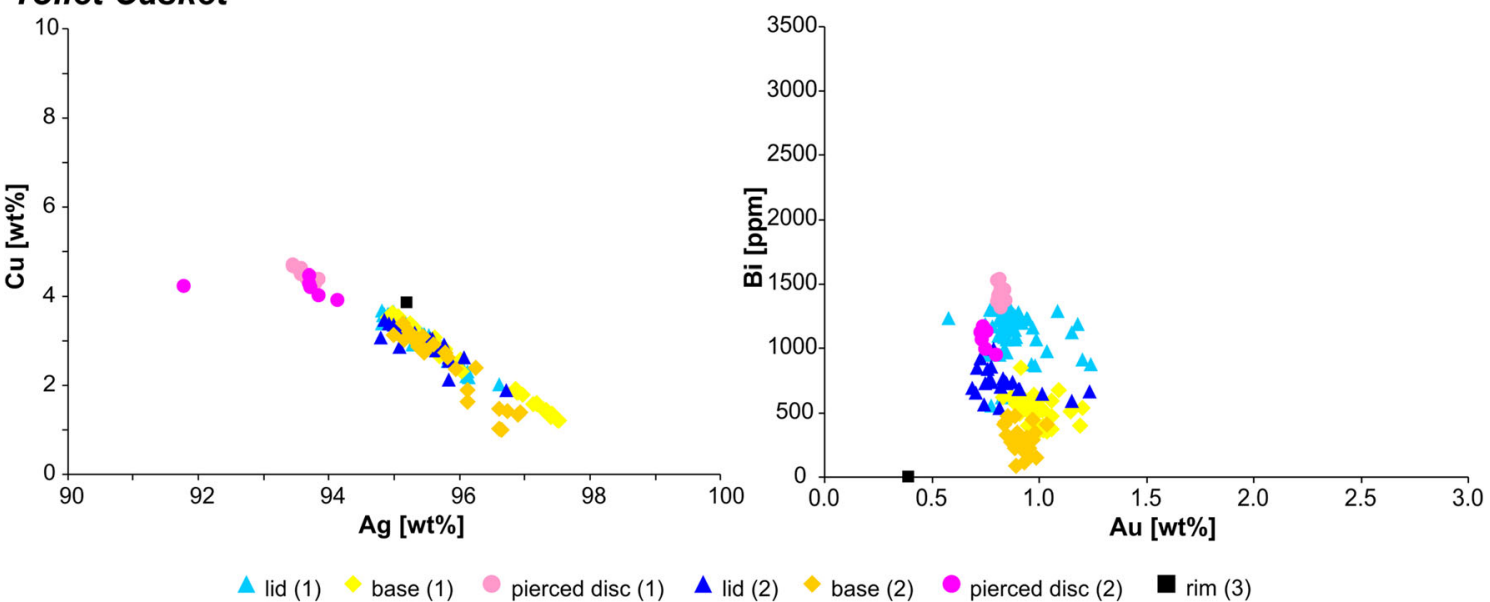

Fig. 4 Silver vs. copper and gold vs. bismuth content of the Hippolytus Situlas and the Toilet Casket based on the hXRF measurements, previous ICP-OES data are shown for comparison. Measured with

1: Niton X13t GOLDD+; 2: SPECTRO xSORT Combi; 3: ICP-OES (Mango and Bennett 1994)

The various parts of the two Hippolytus Situlas (handle, feet, body and upper beaded rim) differ chemically from each other. The upper beaded rims have the highest silver content of all the Seuso objects; in fact, they were manufactured from 
almost pure silver (> $99 \mathrm{wt} \%$ ) (Fig. 4). The gold content is heterogeneous. The feet have the highest gold content $(0.7-$ $1.1 \mathrm{wt} \%)$, while the upper beaded rim has the lowest $(0.2-0.5$ $\mathrm{wt} \%)$. The gold content of the handles and the bodies is similar $(0.5-1.0 \mathrm{wt} \%)$. The lead content is constant and falls below $1 \mathrm{wt} \%$, whereas the bismuth content is heterogeneous, ranging from 0 to 1500 ppm (Fig. 4; Online Resource 2).

The parts (lid, base, pierced disc) of the Toilet Casket have different chemical compositions, indicating that they were manufactured from silver alloys of different compositions. The pierced disc contains the most copper (3.9-4.7 wt\%), and the lid and base contain similar amounts of copper (1.0 $3.7 \mathrm{wt} \%$ ) (Fig. 4). The gold and lead contents are constant and fall below or around $1 \mathrm{wt} \%$ (Fig. 4; Online Resource 2). Bismuth is present in slightly lower concentrations in the base (100-900 ppm) than in the lid (500-1300 ppm) and the pierced disc (1000-1500 ppm) (Fig. 4).

\section{Gilding}

Each of the composite objects was selectively gilded, except the Toilet Casket, and the gilding is quite worn in some places (Fig. 5). The gilding was analysed at several points, ranging from 2 to 60 points per object, depending on the object and the extent of the gilded surfaces. The gold content of the gilded surfaces ranges from 1.0 to $76.2 \mathrm{wt} \%$ depending on the thickness of the gilding (Online Resource 3). The relative thickness of the gilding was estimated based on the macroscopic observations and on the gold content of the gilded areas. In the case of the Amphora, Animal Ewer, Dionysiac Ewer and the Hippolytus set, mercury was detected in the gilded parts (Fig. 5g). Gold spans the edge of the gilded area, particularly in the case of the Animal Ewer, whose flat surfaces were gilded. On the ribs of the Animal Ewer, which separate the different sections of the body, gilding was not observed by the naked eye, only at the very edges, in deeper depressions, but the elevated gold content indicates that the entirety of the ribs was originally gilded (Online Resource 3; Fig. 5a, b). In contrast, the gilding of the two Geometric Ewers was analysed in 61 and 68 points, respectively, and no mercury was detected in any of analysed points by the handheld XRF (Fig. 5g). The gilding appears to be very thin, is pale yellow and generally follows the decoration lines (Fig. 5e, f).

\section{Soldering}

The various parts of the Seuso objects were assembled in different ways. The joints were analysed at several points, ranging from one to seven points per object. At the joints of handles, feet, lids and thumbpieces, as well as at the ancient repairs, elevated tin and lead contents were measured (1.4$70.1 \mathrm{wt} \% \mathrm{~Pb} ; 0.8-43.4 \mathrm{wt} \% \mathrm{Sn}$ ), indicating the use of a soft lead-tin solder (Online Resource 3; Fig. 6e). The soldering material completely recrystallised, resulting in increased volume and a detachment of the soldered parts (handles, thumbpieces, lids) (Fig. 6a-c). At the joints of the bodies and the upper beaded rims of the ewers and the situlas, green copper corrosion products were observed by the naked eye, which manifested in higher copper concentrations (31.9 wt\% $\mathrm{Cu}$ ) (Online Resource 3; Fig. 6d).

\section{Discussion}

\section{Major elements: silver and copper}

Each of the objects was manufactured from high-quality silver, which corresponds well with the observation that high-purity (80-99 wt\% Ag) silver objects were created in the late Roman period (Table 4) (Hughes and Hall 1979; Lang et al. 1984; Feugère 1988; Lang 2002; Tate and Troalen 2009; Cowell and Hook 2010; Hook and Callewaert 2013; Doračić et al. 2015; Lang and Hughes 2016; Greiff 2017; Vulić et al. 2017).

Pure silver is too soft to fashion everyday items from, because it dents, bends and wears easily. In the late Roman period, the most common silver alloying element was copper, as it added strength and hardness to the softer silver. The hardness of an alloy depends not only on its chemical composition but also on the degree of working and heat treatment. The hardness increases quickly up to $15 \%$ copper content, and between 30 and $80 \%$ copper it reaches a rather constant value (Hughes and Hall 1979). As the amount of copper that is added to the molten silver increases, the more yellowish the alloy will become. During silver extraction, the copper content may be reduced to $0.2-1 \%$; thus, higher copper concentrations indicate intentional alloying (Hughes and Hall 1979). The copper content of late Roman silver objects ranges from 0.1 to $15 \%$ (Table 4) (Hughes and Hall 1979; Lang et al. 1984; Feugère 1988; Lang 2002; Tate and Troalen 2009; Cowell and Hook 2010; Hook and Callewaert 2013; Doračić et al. 2015; Lang and Hughes 2016; Greiff 2017; Vulić et al. 2017). The copper content of the Seuso objects fits into this range. The differences in the copper contents of the various parts of the composite objects also indicate intentional alloying:

(i) The parts that are more exposed to mechanical effects, such as handles, bases, rims, lids and feet (e.g. the base and handle of the Amphora, the handles of the Animal, Dionysiac, Hippolytus and Geometric Ewers, the bases of the Geometric Ewers, the pierced disc of the Toilet Casket), were usually made from alloys with higher copper but lower silver contents.

(ii) The parts made with repoussé technique (e.g. the bodies of the Animal, Dionysiac and Hippolytus Ewers, the bodies of the Hippolytus Situlas, the lid and the base of the Toilet Casket) were generally made from alloys 
Fig. 5 Gilding on the Seuso objects. a, b The Animal Ewer: gilding spreads over the edge of the gilded area and is quite worn, invisible with naked eye at the ribs. c The Hippolytus Situla A. d The Amphora. e, f The Geometric Ewers A and B (photo: A. Dabasi and J. Kardos (HNM)). g hXRF spectra of the gilded areas on the examples of the ewers measured with SPECTRO xSORT Combi instrument
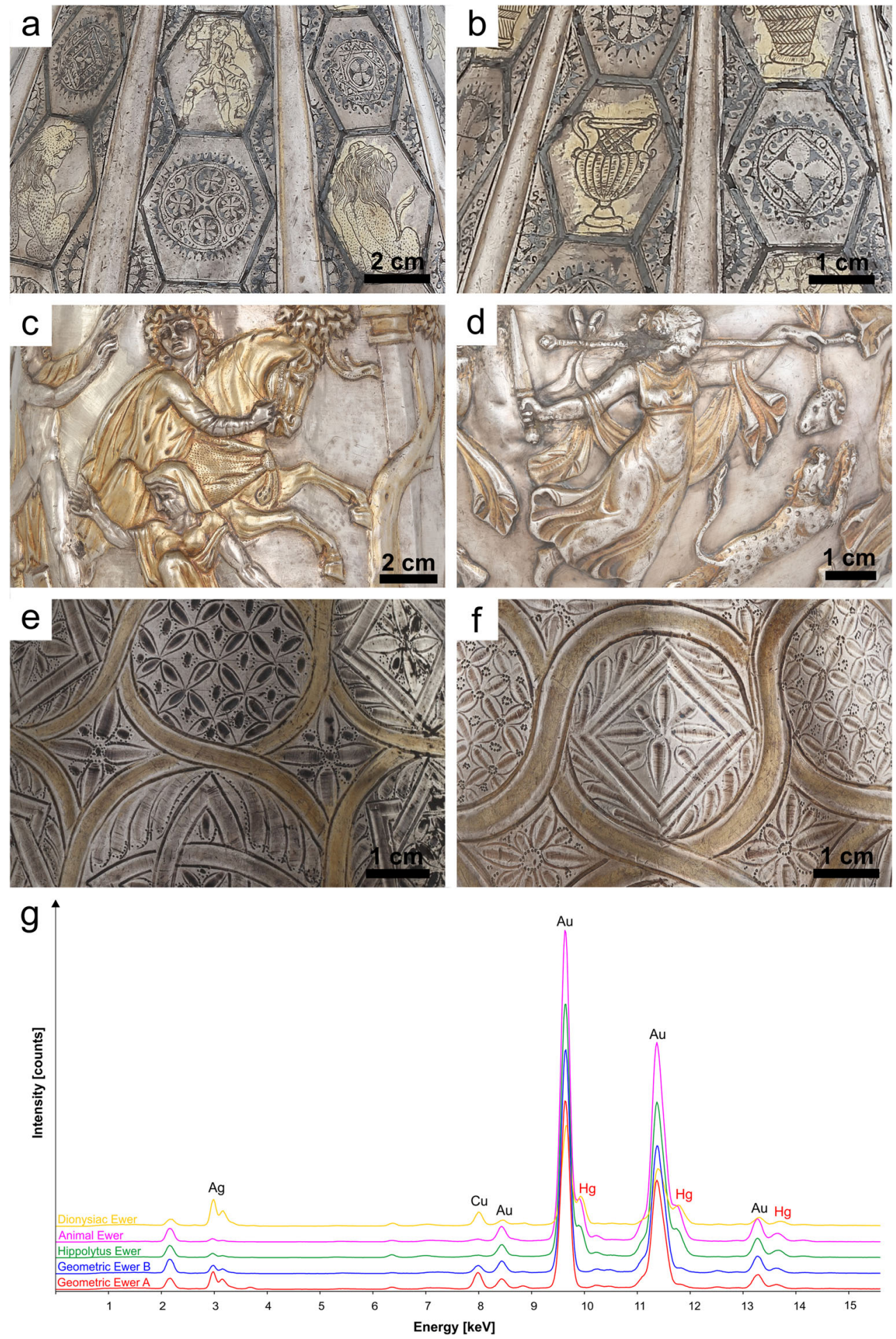

containing a higher percentage of silver, which are more malleable and make it easier to form the small details of the figures and scenes (Greiff 2017).

(iii) The parts that were unequivocally manufactured by casting (handles, thumbpieces, lids, feet, upper beaded and octagonal rims) usually have higher copper contents, because alloys with higher copper contents require a lower melting point, making it easier to cast the alloy. These parts include, e.g. the upper beaded rims of the Animal, Geometric and Hippolytus Ewers, the octagonal rim of the Dionysiac Ewer, handles of the Amphora, the lid of the Animal and Hippolytus Ewers. The upper beaded rims of the Hippolytus Situlas are exceptions; they were cast from almost pure silver (>99 wt\% Ag). The use of silver 
Fig. 6 Solders on the Seuso objects. a Remnants of lead-tin soft solder at the joint of the handle to the body of the Dionysiac Ewer. b Remnants of lead-tin soft solder at the joint of lid to the base of the Toilet Casket and at ancient repairs. c Thick, corroded, recrystallised lead-tin soft solder at the joint of the handle of Geometric Ewer B. d Green copper corrosion products along the rim of the Hippolytus Situla A indicating the use of coppercontaining hard solder (photo: A. Dabasi and J. Kardos (HNM)). e hXRF spectra of the soft solders on the example of the ewers measured with SPECTRO xSORT Combi instrument. Animal Ewer: at the joint of the lid to the body; Dionysiac Ewer: at the joint of the handle to the body; Geometric Ewer B: at the joint of the handle to the body at the beaded rim; Hippolytus Ewer: at the joint of the lid to the body
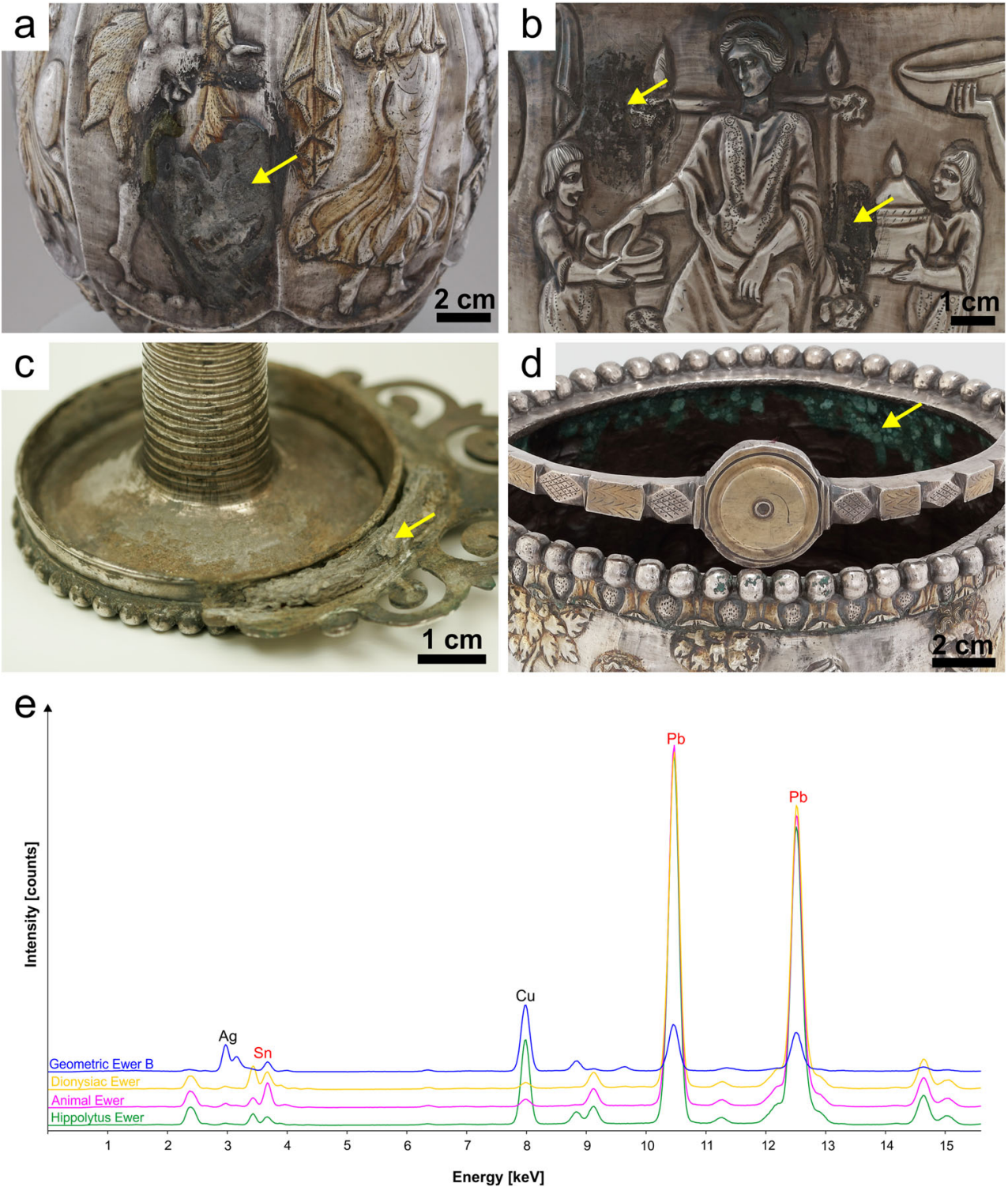

alloys with higher copper contents can also be economic (Mango and Bennett 1994).

The results of the previous ICP-OES measurements made on bulk metal samples taken from the Seuso objects (Mango and Bennett 1994) show the same trends as our hXRF results (Figs. 2, 3 and 4, Online Resource 4). However, as hXRF is a surface analytical method, the effects of corrosion processes are evident: the less noble copper was leached out, and the more noble silver was enriched at the surface. Generally, ICPOES measured higher copper concentrations (0.5-5 wt $\%$ higher) compared to hXRF (Figs. 2, 3 and 4).

\section{Minor and trace elements (impurities)}

With the exception of silver and copper, the measured elements are naturally occurring and unintentionally added, deriving from the silver ore or from the copper used for alloying (Hughes and Hall 1979). Their individual content usually does not exceed $1 \%$ (except for gold at some points in the Animal Ewer, discussion below).

In the Roman period, the primary source of silver was silver-bearing lead ores (Tylecote 1962; Forbes 1971). The silver ores were roasted, melted and cupelled during silver extraction. Cupellation cleansed the silver of impurities (e.g. antimony, arsenic, tin, iron and zinc; less well from copper, gold and bismuth). The volatile elements (antimony, arsenic, mercury, tin and zinc) disappear from the molten silver during cupellation (Pernicka 2014; L'Héritier et al. 2015); however, they can be present in high concentrations (several \%) in native silver (Pernicka 2014). The absence of these volatile elements in the analysed objects indicates that cupelled silver was used for manufacturing. The presence of zinc and tin in some parts of the objects 
Table 4 Chemical composition of contemporaneous silver treasure finds including number of their analysed objects. The results are given in wt\%

\begin{tabular}{|c|c|c|c|c|c|c|c|c|}
\hline Treasure finds & Analytical method & No. of analysed objects & No. of analyses & $\mathrm{Ag}$ & $\mathrm{Cu}$ & $\mathrm{Au}$ & $\mathrm{Pb}$ & $\mathrm{Bi}$ \\
\hline Mildenhall $^{1}$ & $\mathrm{XRF}$ & 20 & 124 & $93.7-98.0$ & $0.3-4.2$ & $0.4-2.6$ & $0.2-2.2$ & \\
\hline Hoxne $^{2}$ & XRF & 96 & 106 & $85.0-99.0$ & $0.1-4.7$ & $0.1-1.0$ & $0.2-4.4$ & $0-0.3$ \\
\hline Kaiseraugst $^{3}$ & $\mathrm{XRF}$ & 8 & 15 & $95.6-98.6$ & $1.0-3.5$ & $0.3-1.3$ & $0.1-0.9$ & \\
\hline Vinkovci ${ }^{4}$ & PIXE & 49 & 56 & $89.1-99.8$ & $0.2-8.9$ & $0.4-3.4$ & $0.1-1.6$ & $0-0.3$ \\
\hline Esquiline $^{5}$ & $\mathrm{XRF}$ & 12 & 32 & $88.6-98.3$ & $0.4-10.3$ & $0.2-4.7$ & $0.6-1.0$ & \\
\hline Coleraine $^{6}$ & $\mathrm{XRF}$ & 30 & 30 & $88.7-97.5$ & $1.2-6.6$ & $0.4-2.2$ & $0.3-2.3$ & \\
\hline Carthage $^{7}$ & $\mathrm{XRF}$ & 20 & 52 & $94.3-97.7$ & $1.9-4.5$ & $0.3-1.1$ & $0.1-0.9$ & \\
\hline Caubiac $(\text { Thil })^{8}$ & XRF & 4 & 4 & $93.8-98.2$ & $1.1-4.3$ & $0.4-0.8$ & $0.2-0.6$ & \\
\hline Trier $^{9}$ & $\mathrm{XRF}$ & 1 & 20 & $81.9-95.1$ & $2.2-14.6$ & $1.1-2.5$ & $0.3-1.9$ & $0-0.2$ \\
\hline Water Newton ${ }^{10}$ & XRF & 13 & 17 & 88.6-97.9 & $1.8-9.9$ & $0.2-4.4$ & $0-0.8$ & \\
\hline Seuso $^{11}$ & $\mathrm{XRF}$ & $14^{\mathrm{a}}$ & 1620 & $79.6-99.4$ & $0.1-18.6$ & $0.2-2.4$ & $0.1-1.5$ & $0-0.3$ \\
\hline
\end{tabular}

${ }^{a}$ The four platters and the Basin of the Seuso Treasure are also included. The minimum-maximum values are given. The number of analyses given for the Seuso Treasure is the sum of the measurements of the two hXRF instruments. ${ }^{1}$ Hughes and Hall 1979; Lang et al. 1977; Lang and Hughes 2016; ${ }^{2}$ Cowell and Hook 2010; ${ }^{3}$ Lang et al. $1984 ;{ }^{4}$ Doračić et al. 2015; Vulić et al. 2017; ${ }^{5}$ Hughes and Hall 1979; ${ }^{6}$ Hook and Callewaert 2013; ${ }^{7}$ Lang 2002 ;

${ }^{8}$ Feugère 1988; ${ }^{9}$ Greiff 2017; ${ }^{10}$ Hughes and Hall 1979; ${ }^{11}$ Mozgai et al. 2017; Mozgai et al. 2020; present study

(0.5-0.8 wt\% Sn in the upper beaded rim and handle of the Animal Ewer; 0.5-0.6 wt\% $\mathrm{Zn}$ in the thumbpiece and handle of the Dionysiac Ewer) indicates that brass and bronze, respectively, were used as alloying metals instead of pure copper. This is supported by the calculated $\mathrm{Cu} / \mathrm{Sn}(\sim 83 \%$ $\mathrm{Cu} ; \sim 17 \% \mathrm{Sn})$ and $\mathrm{Cu} / \mathrm{Zn}(\sim 87 \% \mathrm{Cu} ; \sim 13 \% \mathrm{Zn})$ ratios (Hughes and Hall 1979; Greiff 2017). This alloying practice was indeed unusual in the Roman times, but later, during the Migration Period, it was commonly practised (Craddock et al. 2010; Horváth et al. 2019b; Mozgai et al. 2019). Though it is rare in Roman times, but it is not without example. Elevated $\mathrm{Zn}$ content was found in some of the pieces of the Hoxne hoard and concluded as the result of alloying with brass typical of Roman period (Cowell and Hook 2010). Hughes and Hall (1979) detected elevated zinc content in some bowls from the Chaourse hoard and in some Sassanian objects, and elevated tin content in some objects from the Sutton Hoo hoard, indicating the use of brass or bronze scrap material for alloying.

Ancient Romans produced high-purity silver with a lead content of $0.5-1 \%$ (Hughes and Hall 1979). If silver originates from silver-bearing lead ores (galena, anglesite or cerussite), the lead content in the silver alloy ranges from 0.001 to $3 \%$ (Moorey 1985). The lead content of the analysed Seuso objects falls within this range. The lead contents of the objects differ, because cupellation occurred in multiple steps, which resulted in the different lead contents, or because silver ores from different sources were used. The low and constant lead content indicates that lead was not added to the silver ore during smelting. As such, lead isotope analyses may help to determine the provenance of the raw material. Lead in the silver objects could derive from the alloying metal, if bronze or leaded bronze was used, but in this case, we would expect elevated tin content as well. Therefore, we assume that the lead content of the Seuso objects derives from the silver ore.

Bismuth is also helpful in determining the raw material provenance of silver objects, as its concentration does not change significantly during cupellation (Pernicka and Bachmann 1983; Pernicka 2014; L’Héritier et al. 2015). Dry ores or native silver have bismuth contents below $0.05 \%$ (Craddock 1995), whereas argentiferous galena contains 0.1-1\% bismuth (Gale and Stos-Gale 1981). Based on cupellation experiments, bismuth is oxidised in the final stages of cupellation; therefore, bismuth in silver objects is correlated with the degree of cupellation. However, the final $\mathrm{Bi} / \mathrm{Pb}$ ratio of the cupelled silver depends on the initial Bi content of the silver-bearing lead ores (L'Héritier et al. 2015). The $\mathrm{Bi} / \mathrm{Pb}$ ratio indicates that the Seuso objects can be categorised as having a homogeneous $\mathrm{Bi} / \mathrm{Pb}$ ratio or a heterogeneous $\mathrm{Bi} / \mathrm{Pb}$ ratio in the various parts of the composite objects. The Dionysiac Ewer has the highest $\mathrm{Bi} / \mathrm{Pb}$ ratio (Table 3, Fig. 7). The body, base, handle and thumbpiece have similar compositions, although the octagonal rim shows the highest $\mathrm{Bi} / \mathrm{Pb}$ ratio of all the objects. The Animal Ewer and Geometric Ewers $\mathrm{A}$ and $\mathrm{B}$ have a very similar and homogeneous $\mathrm{Bi} / \mathrm{Pb}$ ratio, whereas the Hippolytus Ewer and the Amphora have a heterogeneous $\mathrm{Bi} / \mathrm{Pb}$ ratio. The bismuth contents of the body and the handles of the Amphora fall below the detection limit of the XRF $(\sim 150$ and $\sim 60 \mathrm{ppm}$, respectively, Online Resource 1). The base and stopper are characterised by a low and a high $\mathrm{Bi} / \mathrm{Pb}$ ratio, respectively. The $\mathrm{Bi} / \mathrm{Pb}$ ratios of the body, handle and lid of the Hippolytus Ewer are similar to the ratios of the Animal and Geometric Ewers, while the upper beaded rim and the base have higher $\mathrm{Bi} / \mathrm{Pb}$ ratios (Table 3, Fig. 7). The $\mathrm{Bi} / \mathrm{Pb}$ ratios of the Toilet Casket and Hippolytus Situla A and B are low and homogeneous, with the exception 
of the upper beaded rims of the situlas, which exhibit heterogeneous $\mathrm{Bi} / \mathrm{Pb}$ ratios (Fig. 7). The differences in the $\mathrm{Bi} / \mathrm{Pb}$ ratios indicate that different silver ingots were used to make the different parts of the objects.

Gold is completely miscible with silver. During metallurgical processes, the gold content of silver does not change drastically (L'Héritier et al. 2015). Consequently, the Au/Ag ratio does not alter during cupellation (Pernicka 2014). The gold content of argentiferous galena ranges from 0.01 to $1 \%$, whereas the gold content of cerussite and anglesite ranges between 0.1 and $0.5 \%$ (Karydas et al. 2004 and references herein). The gold content of late Roman silver objects falls between 0.1 and 4.7\% (Table 4) (Hughes and Hall 1979; Lang et al. 1984; Feugère 1988; Lang 2002; Tate and Troalen 2009; Cowell and Hook 2010; Hook and Callewaert 2013; Doračić et al. 2015; Lang and Hughes 2016; Greiff 2017; Vulić et al. 2017). There are several reasons that gold concentrations exceed $1 \%$, such as the presence of remnants of former gilding, the re-usage of scrap gilded silver or the use of gold-silver ores. The gold content of the Seuso objects shows constant values and falls within the range typical of late Roman objects. This indicates that primary silver ore was used during manufacture, instead of the re-usage of scrap silver, which would result in a wide range of variation in the gold values. The differences in the gold content of the Seuso objects indicate the use of different ingots.

The similarities and differences in the chemical compositions of the various parts of the objects support the technological observations (Mango and Bennett 1994; Dági and Mráv, 2019). The different compositions of the various parts of the objects indicate the use of different ingots. Based on their manufacturing techniques, the ewers can be classified into two groups: (i) the body and the base were cast or raised from a single silver sheet (e.g. Animal and Dionysiac Ewers) and (ii) the body and base were made separately and were later joined mechanically (e.g. Hippolytus Ewer and Geometric Ewers A and B).

The previous ICP-OES analyses (Mango and Bennett 1994, Online Resource 4) systematically measured lower gold contents in the bulk metal samples compared to our hXRF values (Figs. 2, 3 and 4), possibly due to digestion problems; thus, they are not included in this research. However, the bismuth contents compared well and showed the same trend as the hXRF results (Figs. 2, 3 and 4). Furthermore, our analysis also completes the previous ICP-OES measurements, as we determined the chemical composition of each part of the Hippolytus Ewer and the Toilet Casket and demonstrated the use of different silver ingots for their manufacture.

When our results are compared to other contemporaneous silver hoards, it is evident that most of them primarily contain platters, plates and bowls, which were generally manufactured from a single silver batch. The Seuso Treasure is unique, because it is mostly composed of large, composite objects (ewers, amphora, situlas, casket) that were manufactured from several parts. Ewers, the casket and the amphora from the Trier, Vinkovci and Esquiline hoards were analysed at several points (Online Resource 5) (Hughes and Hall 1979; Doračić et al. 2015; Greiff 2017; Vulić et al. 2017). Of these objects, the Apostle jug from Trier exhibits a noticeable chemical difference between the various parts, indicating that it was not manufactured from one, large, uniform batch of silver. The body, which is heavily decorated, has the highest silver content (93.9-95.1 wt\% Ag), whereas the handle and the thumbpieces exhibit higher copper concentrations (81.9$95.0 \mathrm{wt} \%$ ) (Online Resource 5) (Greiff 2017). This chemical difference between the various parts of the Apostle jug is very similar to that of the ewers in the Seuso Treasure.

\section{Gilding}

The hXRF data show that the Seuso objects were decorated with two types of gilding: (i) fire gilding, which contained mercury; and (ii) a different gilding technique that did not contain mercury. Mercury was detected in the gilding of the Amphora, Dionysiac Ewer, Animal Ewer and the Hippolytus set, indicating the use of fire gilding. In contrast, mercury was absent from the gilding of Geometric Ewers A and B, indicating the possible use of a different gilding technique (Fig. 5).
Fig. $7 \mathrm{Au} / \mathrm{Ag}$ vs. $\mathrm{Bi} / \mathrm{Pb}$ ratio of the Seuso objects based on the hXRF measurements. Measured with Niton Xl3t GOLDD+ (lighter colours) and SPECTRO xSORT Combi (darker colours) instruments
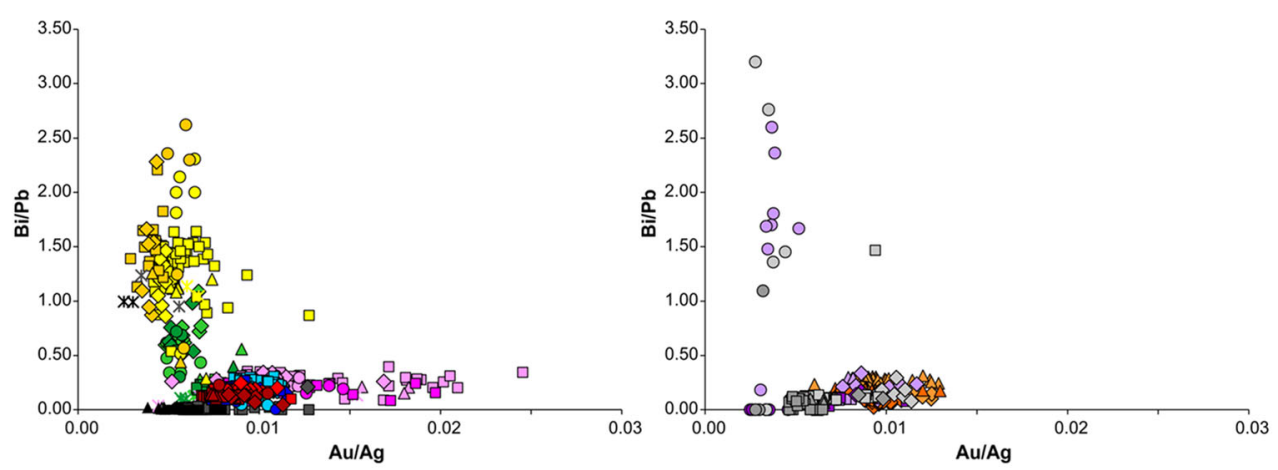

Amphora Animal Ewer Dionysiac Ewer Geometric Ewer A Geometric Ewer B Hippolytus Ewer Hippolytus Situla A Hippolytus Situla B Toilet Casket $\square$ bodies $O$ upper beaded/octagonal rims/pierced disc $\Delta$ handles/lid $\diamond$ bases/feet $*$ lids/stopper/thumbpieces 
Fire gilding was likely invented in China in the fourth century BC (Lechtman 1971; Lins and Oddy 1975; Oddy 1981, 1988, 1991, 1993, 2000). In the fire gilding technique, gold was dissolved in hot mercury, and the resulting gold amalgam was rubbed on to the cleaned metal surface, after which the object was heated for a few minutes at $250-300{ }^{\circ} \mathrm{C}$ (below the boiling point of mercury, $357^{\circ} \mathrm{C}$ ) until it changed from silver to yellow. It is important to avoid overheating the object. If silver is overheated, the gold discolours or even disappears into the substrate. This phenomenon restricts the maximum firing temperatures to approximately $350{ }^{\circ} \mathrm{C}$. A firmly bonded but porous, matte gilded layer will form, which must then be burnished. This technique is still used in Nepal (Anheuser 1997; Oddy 2000). In the Roman period, fire gilding was considered by Pliny the Elder (first century AD) to be a costly and rarely utilised method. However, it became the standard method of gilding in the third-fourth centuries AD and continued to be used throughout medieval Europe, until the invention of electroplating in the mid-nineteenth century AD (Lechtman 1971; Lins and Oddy 1975; Oddy 1981, 1988, 1991, 1993, 2000). As such, the presence of mercury is common in the gilding of third century AD Roman objects, but rare in the gilding of earlier Roman objects. This may be because supplies of mercury became more available for common use in the third century AD. Another method of fire gilding is to apply a layer of mercury to the metal surface to be gilded and then lay pieces of gold leaf on top. The gold leaf dissolves in the mercury, creating a gold amalgam in situ, after which the object is heated and burnished. This method is still used in Japan (Anheuser 1997; Oddy 2000). Anheuser's (1997) experiments showed that 8-25\% of mercury is retained during fire gilding and can be detected later on. The typical macroscopic features of fire gilding, such as gold spreading over the edge of the gilded area, splashes of gold on ungilded areas and thicker gold deposits in engraved lines, were observed on the Seuso objects (Fig. 5a-d). Fire gilding was the typical gilding method used on other contemporaneous late Roman silver hoards (Lang et al. 1984; Feugère 1988; Hughes et al. 1989; Cowell and Hook 2010; Hook and Callewaert 2013; Doračić et al. 2015; Lang and Hughes 2016; Greiff 2017; Vulić et al. 2017).

The two types of gilding on the Seuso objects were also supported by Mango and Bennett (1994), using mercury in both cases: (i) a gold amalgam was prepared and rubbed onto the surface of the object, after which the object was heated and the mercury evaporated; (ii) the surface of the object was amalgamated by rubbing mercury on to it or by dipping it into a solution of soluble mercury salt, and then gold leaf (sometimes several layers) was laid on top, after which the object was heated as before. It was thought that the Geometric Ewers were gilded by the first method, whereas the Dionysiac Ewer, Animal Ewer and the vessels of the Hippolytus set were decorated with the second method. The gilding of the Amphora was too worn to determine the method used (Mango and Bennett 1994). Our present data do not support the use of fire gilding for the Geometric Ewers, as mercury is always detectable in fire gilding (Anheuser 1997) but is absent from the Geometric Ewers. Further invasive investigations are planned to confirm whether diffusion bonding was used on the Geometric Ewers. It is possible to bond gold leaf to pure silver (or to pure copper) without the use of an adhesive, by burnishing and minimally heating the object to promote interdiffusion between the gold and silver. Diffusion bonding (or hot cladding) was invented as early as 1200 BC, and was commonly used on silver from the late Hellenistic and early Roman periods (Lechtman 1971; Oddy et al. 1981; Oddy 1981, 1988, 1991, 1993, 2000). This method of gilding is thus far not found on Roman silver objects from the fourth century AD. However, microscopic examinations of Roman objects from the Chaourse (second-third centuries AD) and Mâcon Treasures (third century AD) (Hughes et al. 1989), as well as of several earlier objects (e.g. an Elamite dish and a Parthian bowl) (Oddy 1988), revealed the presence of diffusion bonded gilding on these objects.

The lack of mercury could indicate some sort of restoration, during which gilding could be lost due to, e.g. repeated annealing, and was subsequently replaced. If the lack of mercury would indicate some restoration, then it is highly unlikely that the complete gilding of the Geometric Ewers was restored and no sign of restoration was found on the other Seuso objects. Moreover, based on the description of the restoration process performed in 1989 (Mango and Bennett 1994), no such restoration, which would provide enough heat to drive off the mercury, was performed on the Seuso objects.

Higher gold concentrations were measured at several points on the Animal Ewer, in places where gilding could not be seen by the naked eye (Fig. 5a, b). Mercury was also detected at these points. These are residues of former gilding, in which the gold diffused into the silver, but the gilding became worn over time.

\section{Assembling of the objects-joining techniques}

There are several ways to join the different parts of a composite silver object: (i) make simple linkages by folding the edges of the metal; (ii) use pins, rivets or twisted components; or (iii) create a joint by applying heat to metal (e.g. welding, casting on, sintering, brazing and soldering). Both brazing (or hard soldering) and soft soldering require the use of filler metal, such as low-temperature lead-tin soft solders, hightemperature silver-copper hard solders and intermediate temperature alloys of silver and mercury or of silver and tin (Lang and Hughes 1977, 1984, 1988).

The various parts of the composite Seuso objects were assembled in three different ways. The bases of the Hippolytus and Geometric Ewers were mechanically attached 
to the body by inserting the bases of the ewers into a hole in the foot and hammering the metal (Mango and Bennett 1994). The handles, lids, feet and thumbpieces were attached with using lead-tin soft solders (Fig. 6). Lead-tin soft solders were also used for ancient repairs (e.g. on the body of the Amphora). The upper beaded and octagonal rims were attached to the body with silver-copper hard solders, indicated by the presence of green copper corrosion products (Fig. 6). The use of these soldering materials was common in the late Roman period (Lang and Hughes 1988). Hard soldering occurs at a higher temperature, which may be near to the melting point of the body metal. In contrast, soft soldering requires a lower melting point alloy and occurs at a much lower temperature than the melting point of the body metal (Lang and Hughes 1977). The temperature range of the solders available to ancient Roman craftsmen varied from the melting point of silver $\left(960{ }^{\circ} \mathrm{C}\right)$ to Tinman's solder containing $66 \%$ tin and $34 \%$ lead, which is very close to the eutectic point of the system $\left(183{ }^{\circ} \mathrm{C}\right)$ (Lang and Hughes 1984). The differences in the chemical compositions of the soft solders potentially indicate the use of different soldering alloys and different working temperatures. The behaviour of a solder primarily depends on its composition, as well as on the conditions under which the soldering is performed (e.g. temperature, surface finish, flux, reducing or oxidising atmosphere). If several operations must be executed, the highest melting point solders must be used first (Lang and Hughes 1988).

\section{Conclusions}

Non-destructive handheld X-ray fluorescence spectrometry is a useful tool in the determination of the chemical composition of composite silver objects, if a significant number of analyses are performed and the same instrument is used for the measurements. With enough analyses, the inhomogeneity amongst the various parts of the objects and the similarities and differences between the objects can be revealed, and the objects can be classified. Moreover, raw materials, manufacturing and decoration techniques used can be characterised, which help to better reconstruct past technological practices and craftsmanship.

The chemical composition of the objects of the Seuso Treasure shares similarities with other late Roman period silver finds. The differences in the chemical composition of the various parts of the composite objects are clear evidence that different ingots of silver were used for each part, which supports the earlier technological observations (Mango and Bennett 1994). The different copper contents explain the use of intentional alloying. The constant gold content implies that the objects were not manufactured from reused or remelted scrap silver. The likewise constant and low lead content indicates the use of cupelled silver. Based on the $\mathrm{Bi} / \mathrm{Pb}$ ratio the objects can be categorised, which suggests that different silver ingots were utilised. The ewers were constructed in two ways: (i) the base and the body were made separately, or (ii) the base and the body were raised or cast from a single silver sheet. The composite objects were assembled following three methods: (i) mechanical attachment, (ii) lead-tin soft solders or (iii) copper-silver hard solders. Two types of gilding were used for decoration, one with remnants of mercury (fire-gilding) and another without mercury (presumably diffusion bonding).

The results of previous studies performed on the Seuso objects were interpreted and new observations were made, specifically, that the chemical composition of every part of every object (including the Toilet Casket and Hippolytus Ewer) was determined, that the gilding and soldering of each object were identified. Regarding the Geometric Ewers, diffusion bonding was likely used instead of fire gilding, as previously hypothesised. The hXRF data serve as a guide with which to select sites to sample (with minimal invasiveness) for further lead isotope and bulk elemental composition analyses, the results of which will be published in a subsequent paper.

Supplementary Information The online version contains supplementary material available at https://doi.org/10.1007/s12520-021-01321-4.

Acknowledgements The hXRF measurements were performed within the framework of the Seuso Research Project supported by the State of Hungary from 2014 to 2019. The authors are grateful to Balázs Lencz, Tamás Szabadváry and András Szabó at the Hungarian National Museum for their help during hXRF analysis. Ariana Gugora is thanked for proofreading the manuscript. Furthermore, the authors are thankful to Mária Tóth, Norbert Németh and Balázs Lencz for providing the silver reference materials.

Funding Open access funding provided by ELKH Research Centre for Astronomy and Earth Sciences.

Open Access This article is licensed under a Creative Commons Attribution 4.0 International License, which permits use, sharing, adaptation, distribution and reproduction in any medium or format, as long as you give appropriate credit to the original author(s) and the source, provide a link to the Creative Commons licence, and indicate if changes were made. The images or other third party material in this article are included in the article's Creative Commons licence, unless indicated otherwise in a credit line to the material. If material is not included in the article's Creative Commons licence and your intended use is not permitted by statutory regulation or exceeds the permitted use, you will need to obtain permission directly from the copyright holder. To view a copy of this licence, visit http://creativecommons.org/licenses/by/4.0/.

\section{References}

Angelini I, Canovaro C, Venturino M, Artioli G (2019) The silver treasure of Marengo: silver provenancing and insights into late antiquity Roman and Gallo-Roman hoards. Archaeol Anthropol Sci 11:49594970. https://doi.org/10.1007/s12520-019-00851-2 
Anheuser K (1997) The practice and characterization of historic fire gilding techniques. The Journal of The Minerals. Metals \& Materials Society (TMS) 49:58-62. https://doi.org/10.1007/s11837-9970015-6

Arias C, Pagnotta S, Campanella B, Poggialini F, Legnaioli S, Palleschi V, Murolo C (2019) The mysteries of the Baratti Amphora. Open Access Journal of Archaeology and Anthropology 1(3):1-4. https:// doi.org/10.33552/OAJAA.2019.01.000512

Asderaki-Tzoumerkioti E, Karydas AG (2011) XRF analyses of four silver gilded Hellenistic epaulettes. In: Turbanti-Memmi I (ed) Proceedings of the $37^{\text {th }}$ International Symposium on Archaeometry. Springer-Verlag, Berlin, Heidelberg, pp 569-574. https://doi.org/10.1007/978-3-642-14678-7 82

Beck L, Réveillon S, Bosonnet S, Eliot D, Pilon F (2003) Experimental evidence of direct surface enrichment on silver-copper alloys. Application to the analysis of ancient silver coins. In: Archaeometallurgy in Europe: International Conference: 24-25-26 September Milan, Italy: Proceedings Vol. 2, Associazione Italiana di Metallurgia, Milan, pp 561-568

Beck L, Bosonnet S, Réveillon S, Eliot D, Pilon F (2004) Silver surface enrichment of silver-copper alloys: a limitation for the analysis of ancient silver coins by surface techniques. Nucl Inst Methods Phys Res B 226:153-162. https://doi.org/10.1016/j.nimb.2004.06.044

Berthoud T, Hurtel LP, Menu M (1988) Études analytiques d'objects en argent romains: Bilan et perspectives (á propos du trésor Boscoreale). In: Baratte F, Duval N (eds) Argenterie romaine et byzantine: actes de la table ronde, Paris 11-13 octobre 1983 Archéologie de l'antiquité tardive. De Boccard, Paris, pp 35-50

Brand NW, Brand CJ (2014) Performance comparison of portable XRF instruments. Geochemistry: Exploration, Environment, Analysis 14: 125-138. https://doi.org/10.1144/geochem2012-172

Caridi F, Torrisi L, Cutroneo M, Barreca F, Gentile C, Serafino T, Castrizio D (2013) XPS and XRF depth patina profiles of ancient silver coins. Appl Surf Sci 272:82-87. https://doi.org/10.1016/j. apsusc.2012.02.071

Cesareo R, Ridolfi S, Marabelli M, Castellano A, Buccolieri G, Donativi M, Gigante GE, Brunetti A, Rosales Medina MA (2008) Portable systems for energy-dispersive $\mathrm{X}$-ray fluorescence analysis of works of art. In: Potts PJ, West M (eds) Portable X-ray fluorescence spectrometry: capabilities for in situ analysis. The Royal Society of Chemistry, Cambridge, pp 206-246

Cowell M, Hook D (2010) The analysis of the metal artefacts. In: Johns C (ed) The Hoxne Late Roman Silver Treasure: gold jewellery and silver plate. British Museum Press, London, pp 175-183

Craddock PT (1995) Early Metal Mining and Production. Edinburgh University Press, Edinburgh

Craddock P, Cowell M, Hook D, Hughes M, La Niece S, Meeks N (2010) Change and stasis: the technology of Dark Age metalwork from the Carpathian Basin. The British Museum Technical Research Bulletin 4:55-65

Dági M, Mráv Zs (2019) The Seuso Treasure - The Splendour of Pannonia. Hungarian National Museum, Budapest

Doračić D, Lang J, Fletcher P (2015) Late Roman silver hoard from Vinkovci, Croatia - a preliminary technological overview. Hist Metall 49(2):87-95

Feugère M (1988) Le trésor d'argenterie gallo-romaine de Thil (HauteGaronne) dit Trésor de Caubiac. In: Baratte F, Duval N (eds) Argenterie romaine et byzantine: actes de la table ronde, Paris 1113 octobre 1983 Archéologie de l'antiquité tardive. De Boccard, Paris, pp 63-80

Forbes RJ (1971) Studies in Ancient Technology. Volume VIII. Metallurgy in Antiquity Part 1: Early metallurgy; the smith and his tools; gold, silver and lead, zinc and brass. Brill Ltd., Leiden

Frahm E, Doonan RCP (2013) The technological versus methodological revolution of portable XRF in archaeology. J Archaeol Sci 40:14251434. https://doi.org/10.1016/j.jas.2012.10.013
Gale NH, Stos-Gale ZA (1981) Ancient Egyptian Silver. J Egypt Archaeol 67:103-115. https://doi.org/10.2307/3856605

Greiff S (2017) Chemisch-analytische Untersuchungen der Trierer Silberkanne. In: Kaufmann-Heinimann A, Martin M (eds) Die Apostelkanne und das Tafelsilber im Hortfund von 1628, Trierer Silberschätze des, vol 5. Jahrhunderts. Rheinisches Landesmuseum, Trier, pp 158-170

Hall ET (1961) Surface enrichment of buried metals. Archaeometry 4: 62-66. https://doi.org/10.1111/j.1475-4754.1961.tb00535.x

Hook D, Callewaert M (2013) Appendix 2: The scientific examination and analysis of some of the Roman silver artefacts from the Coleraine treasure. In: Hunter F, Painter K (eds) Late Roman Silver: The Traprain Treasure in Context. Society of Antiquaries of Scotland, Edinburgh, pp 184-187

Horváth E, Mozgai V, Bajnóczi B (2019a) Pure gold with poor workmanship - some unusual pieces of polychrome metalwork from the $5^{\text {th }}$-century Carpathian Basin. Archeometriai Mühely 16(1):43-56 http://www.ace.hu/am/2019 1/AM-2019-1-HE.pdf

Horváth E, Mozgai V, Topa BA, Szabó M, Bajnóczi B (2019b) Fine metalwork between two periods: tracing changes in goldsmithing tradition and craft organisation in the mid-to-late $5^{\text {th }}$-century Carpathian Basin by the investigation of polychrome goldsmiths' works. In: $5^{\text {th }}$ International Conference Archaeometallurgy in Europe - Book of Abstracts, Miskolc, Hungary, p 23

Hrnjić M, Hagen-Peter GA, Birch T, Hoffmann Barfod G, Sindbæk SM, Lesher CE (2020) Non-destructive identification of surface enrichment and trace element fractionation in ancient silver coins. Nucl Inst Methods Phys Res B 478:11-20. https://doi.org/10.1016/j. nimb.2020.05.019

Hrnjić M, Röhrs S, Denker A, Weisser B, Stoess C, Matosz M, Del HoyoMeléndez JM (in press) Multi-technical study of silver denars from medieval Poland for an improved understanding of their archaeological context and provenance. Archaeometry. https://doi.org/10. $1111 /$ arcm. 12624

Hughes MJ, Hall JA (1979) X-ray fluorescence analysis of Late Roman and Sassanian silver plate. J Archaeol Sci 6:321-344. https://doi. org/10.1016/0305-4403(79)90017-7

Hughes M, Lang J, La Niece S, Oddy A (1989) Technologie de l'argenterie romaine. In: Baratte F, Painter K (eds) Tresors d'orfevrerie gallo-romains. Ministère de la Culture, de la Communication, des Grands Travaux et du Bicentenaire, Éditions de la Réunion des musées nationaux, Paris, pp 21-53

Karydas AG, Kotzamani D, Bernard R, Barrandon JN, Zarkadas C (2004) A compositional study of a museum jewellery collection $\left(7^{\text {th }}-1^{\text {st }} \mathrm{BC}\right)$ by means of a portable XRF spectrometer. Nucl Inst Methods Phys Res B 226:15-28. https://doi.org/10.1016/j.nimb. 2004.02 .034

Lang J (2002) Le Trésor de Carthage. Étude technique. In: Baratte F, Lang J, La Niece S, Metzger C (eds) Le Trésor de Carthage: contribution à l'étude de l'orfévrerie de l'antiquité tardive. CNRS Éditions, Paris, pp 89-105

Lang J, Hughes MJ (1977) Joining techniques. In: Oddy WA (ed) Aspects of early metallurgy. Historical Metallurgy Society and British Museum, London, pp 169-177

Lang J, Hughes MJ (1984) Soldering Roman silver plate. Oxf J Archaeol 3(3):77-106. https://doi.org/10.1111/j.1468-0092.1984.tb00124.x

Lang J, Hughes MJ (1988) Soldering on late Roman silver. In: Baratte F, Duval N (eds) Argenterie romaine et byzantine: actes de la table ronde, Paris 11-13 octobre 1983 Archéologie de l'antiquité tardive. De Boccard, Paris, pp 27-33

Lang J, Hughes M (2016) The Mildenhall treasure: technical aspects of construction and decoration. In: Hobbs R (ed) The Mildenhall Treasure: Late Roman Silver Plate from East Anglia. British Museum Press, London, pp 240-249

Lang J, Hughes MJ, Oddy WA (1984) Report on the scientific examination of the Sea City Dish 62, the Achilles Dish 63 and some other 
Items. In: Cahn HA, Kaufmann-Heinimann A (eds) Der spätrömische Silberschatz von Kaiseraugst. Basler Beiträge zur Ur- und Frühgeschichte 19, Derendingen, pp 375-381

Lang JRS, Meeks ND, Wheatley CJ, Cowell MR (1977) Appendix A: the scientific examination of the great dish. In: Painter KS (ed) The Mildenhall Treasure. Roman Silver from East Anglia. Trustees of the British Museum, pp 35-40

Lechtman HN (1971) Ancient methods of gilding silver: examples from the old and the new worlds. In: Brill RH (ed) Science and Archaeology. Cambridge, pp 2-30

Lehmann R, Fellenger D, Vogt C (2014) Modern metal analysis of Bronze Age gold in Lower Saxony by using laser ablation mass spectrometry (ns-LA-ICP-QMS and fs-LA-ICP-MCMS) and portable X-ray fluorescence (pXRF). In: Meller HH, Risch R, Pernicka E (eds) Metals of power - Early gold and silver - Part 1. Halle (Saale), pp 237-246

Lejček P, Kovač J, Vaníčková J, Děd J, Samardžija Z, Zalar A (2010) Copper surface enrichment of Ag-Cu alloys. Surf Interface Anal 42: 662-665. https://doi.org/10.1002/sia.3170

L'Héritier M, Baron S, Cassayre L, Téreygeol F (2015) Bismuth behaviour during ancient processes of silver-lead production. J Archaeol Sci 57:56-68. https://doi.org/10.1016/j.jas.2015.02.002

Lins PA, Oddy WA (1975) The Origins of Mercury Gilding. J Archaeol Sci 2:365-373. https://doi.org/10.1016/0305-4403(75)90007-2

Mango MM, Bennett A (1994) The Seuso Treasure Part 1. Journal of Roman Archaeology Supplementary Series Number 12, Ann Arbor, Michigan

Maryon H (1971) Metalwork and enamelling - a practical treatise on gold and silversmiths' work and their allied crafts. Dover Publications, Inc., New York

Mass J, Matsen C (2013) Quantitative non-destructive analysis of historic silver alloys: X-ray fluorescence approaches and challenges. In: Shugar AN, Mass JL (eds) Handheld XRF for art and archaeology. Studies in Archaeological Sciences 3, Leuven University Press, Leuven, pp 215-247

May Z (2020) Tíz év a hordozható XRF társaságában, azaz egy archeometriai utazás története (Ten years using portable XRF. Our story of a journey in archaeometry). Archeometriai Mühely 17(3): 229-242 http://www.ace.hu/am/2020_3/AM-2020-3-MZ.pdf

McCreight T (1991) The complete metalsmith — an illustrated handbook. Davis Publications, Inc., Worcester, Massachusetts

Melcher M, Schreiner M, Bühler B, Pülz AM, Muss U (2009) Investigation of ancient gold objects from Artemision at Ephesus using portable $\mu$-XRF. ArchèoSciences - revue d'archéometrie 33: 169-175. https://doi.org/10.4000/archeosciences. 2172

Minning S, Ponting M (2013) The West Bagborough hoard, Somerset. In: Hunter F, Painter K (eds) Late Roman Silver: The Traprain Treasure in Context. Society of Antiquaries of Scotland, Edinburgh, pp 275-289

Moorey PRS (1985) Materials and Manufacture in Ancient Mesopotamia. The Evidence of Archaeology and Art, BAR International Series 237. Oxford

Mozgai V, Bajnóczi B, Fórizs I, May Z, Hatvani IG, Dági M, Mráv Zs, Tóth M (2017) Handheld XRF mapping of elemental composition of Roman silver artefacts: preliminary results. In: Montero-Ruiz I, Perea A (eds) Archaeometallurgy in Europe IV. Consejo Superior de Investigaciones Científicas (CSIC), Madrid, pp 237-247

Mozgai V, Szabó M, May Z, Bajnóczi B (2018) Handheld X-ray fluorescence and electron microprobe analyses of gold artefacts of an early Sarmatian grave, Dunakeszi-Székes-dűlő, Hungary. In: Khrapunov I (ed) The Crimea in the Age of the Sarmatians, 200 BC - AD 400. Russian Academy of Sciences (RAN), Szimferopol, pp 42-57

Mozgai V, Horváth E, Miháczi-Pálfi A, Hajnal Zs, Bajnóczi B (2019) Metal composition and decoration techniques of polychrome gold and gilded silver brooches from the $5^{\text {th }}$-century AD Carpathian
Basin. In: Young Researchers in Archaometry 2019 Paris: Maison Archéologie-Ethnologie (MAE, Nanterre), p 1

Mozgai V, Bajnóczi B, May Z, Mráv Zs (2020) A hordozható XRF alkalmazási lehetőségei és korlátai római ezüsttálak archeometriai vizsgálatában (Possibilities and limitations of the use of handheld XRF in the archaeometric study of Roman silver platters). Archeometriai Mühely 17(3):253-270 http://www.ace.hu/am/ 2020 3/AM-2020-3-MV.pdf

Mráv Zs, Dági M (2014) Under the spell of silver-the Seuso Treasure. Hungarian Archaeology summer:1-9 http://files.archaeolingua.hu/ 2014NY/Upload/cikk_Mrav_EN.pdf

Oddy A (1981) Gilding through the ages - an outline history of the process in the old world. Gold Bull 14(2):75-79. https://doi.org/10. 1007/BF03214601

Oddy WA (1988) The gilding of Roman silver plate. In: Baratte F, Duval $\mathrm{N}$ (eds) Argenterie romaine et byzantine: actes de la table ronde, Paris 11-13 octobre 1983 Archéologie de l'antiquité tardive. De Boccard, Paris, pp 9-21

Oddy WA (1991) Gilding: an outline of the technological history of the plating of gold on to silver or copper in the Old World. Endeavour, New Series 15(1):29-33. https://doi.org/10.1016/0160-9327(91) 90085-P

Oddy A (1993) Gilding of metals in the Old World. In: La Niece S, Craddock P (eds) Metal plating and patination - cultural, technical and historical developments. Butterworth-Heinemann Ltd., Oxford, pp 171-181

Oddy A (2000) A history of gilding with particular reference to statuary. In: Drayman-Weisser T (ed) Gilded Metals - History. Technology and Conservation. Archetype Publications, London, pp 1-19

Oddy WA, La Niece S, Curtis JE, Meeks ND (1981) Diffusion-bonding as a method of gilding in Antiquity. Museum Applied Science Center for Archaeology 1(8):238-241

Painter K (1990) The Seuso Treasure. Minerva 1(4):4-11

Pardini L, El Hassan A, Ferretti M, Foresta A, Legnaioli S, Lorenzetti G, Nebbia E, Catalli F, Harith MA, Diaz Pace D, Anabitarte Garcia F, Scuotto M, Palleschi V (2012) X-ray fluorescence and laser-induced breakdown spectroscopy analysis of Roman silver denarii. Spectrochim Acta B 74-75:156-161. https://doi.org/10.1016/j.sab. 2012.06.016

Parreira PS, Appoloni CR, Lobo Vieira RM, Scorzelli RB, Le Corre L, Guerra MF (2009) Precious metals determination in ancient coins by portable ED-XRF spectroscopy with a ${ }^{238} \mathrm{Pu}$ source. ArchéoSciences - Revue d'archéométrie 33:313-318. https://doi. org/10.4000/archeosciences.2396

Pernicka E (2014) Possibilities and limitations of provenance studies of ancient silver and gold. In: Meller HH, Risch R, Pernicka E (eds) Metals of power - Early gold and silver - Part 1. Halle (Saale), pp 153-164

Pernicka E, Bachmann HG (1983) Archäometallurgische Untersuchungen zur antiken Silbergewinnung in Laurion - III. Das Verhalten einigen Spurenelemente beim Abtreiben des Bleis Erzmetall 36:592-597

Sánchez EP, Lansing Maish S (2014) The hidden lives of ancient objects: conserving the Berthouville Treasure and four Missoria. In: Lapatin K (ed) The Berthouville Silver Treasure and Roman Luxury. Getty Publications, Los Angeles CA, pp 107-125

Shackley MS (2012) Portable X-ray fluorescence spectrometry (pXRF): the good, the bad, and the ugly. Archaeology Southwest Magazine 26(2):1-8

Szenthe G, Mozgai V, Horváth E, Bajnóczi B (2019) Ritual deposit from the Hun Period from Telki (Central Hungary): A preliminary report. Hungarian Archaeology spring:9-19. http://files.archaeolingua.hu/ 2019TA/Upload/Szenthe_E191.pdf

Tate J (1986) Some problems in the analysing museum material by nondestructive surface sensitive techniques. Nuclear Instruments and 
Methods in Physics Research B14:20-23. https://doi.org/10.1016/ 0168-583X(86)90417-9

Tate J, Troalen L (2009) Investigating the Traprain Law Roman treasure. Unpublished technical report produced for Eu-Artech. (https:// www.scribd.com/document/215522918/Report-Tate-Troalen)

Tylecote RF (1962) Metallurgy in archaeology. Edward Arnold Publishers, London

Untracht O (1968) Metal techniques for craftsmen — a basic manual for craftsmen on the methods of forming and decorating metals. Doubleday, New York

Vulić H, Doračić D, Hobbs R, Lang J (2017) The Vinkovci treasure of Late Roman silver plate: preliminary report. Journal of Roman Archaeology 30:127-150. https://doi.org/10.1017/ S1047759400074055

Živković J, Rehren T, Radivojević M, Jevtić M, Jovanović D (2014) XRF characterisation of Celtic silver from the Židovar Treasure (Serbia).
In: Pernicka E, Schwab R (eds) Under the Volcano - Proceedings of the International Symposium on the Metallurgy of the European Iron Age (SMEIA) held in Mannheim, Germany, 20-22 April 2010. Verlag Marie Leidorf GmbH, Rahden/Westf., pp 157-173

Zlateva B (2017) Comparison of p-XRF spectrometers for archaeological research: a case study for analysis of tin-rich archaeological bronzes. Global Journal of Archaeology \& Anthropology 2(4):555-591. https://doi.org/10.19080/GJAA.2017.02.555591

Zori C, Tropper P (2013) Silver lining: evidence for Inka silver refining in northern Chile. J Archaeol Sci 40:3282-3292. https://doi.org/10. 1016/j.jas.2013.03.020

Publisher's note Springer Nature remains neutral with regard to jurisdictional claims in published maps and institutional affiliations. 